Universidad de Lima

Facultad de Derecho

Carrera de Derecho

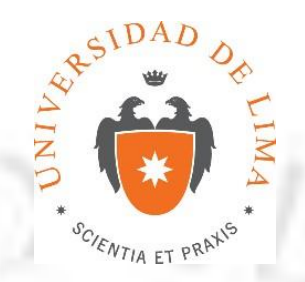

\title{
BENEFICIOS LABORALES ESPECÍFICOS PARA LOS INTERNOS DE MEDICINA: PROPUESTA DE UN PROYECTO DE LEY
}

\author{
Tesis para optar por el título Profesional de Abogado \\ Martha Milagros Astudillo Pedroza \\ Código 20071273 \\ Asesor \\ Germán Ramírez Gastón Ballón \\ Lima - Perú \\ Diciembre de 2016 \\ Universidad de Lima
}




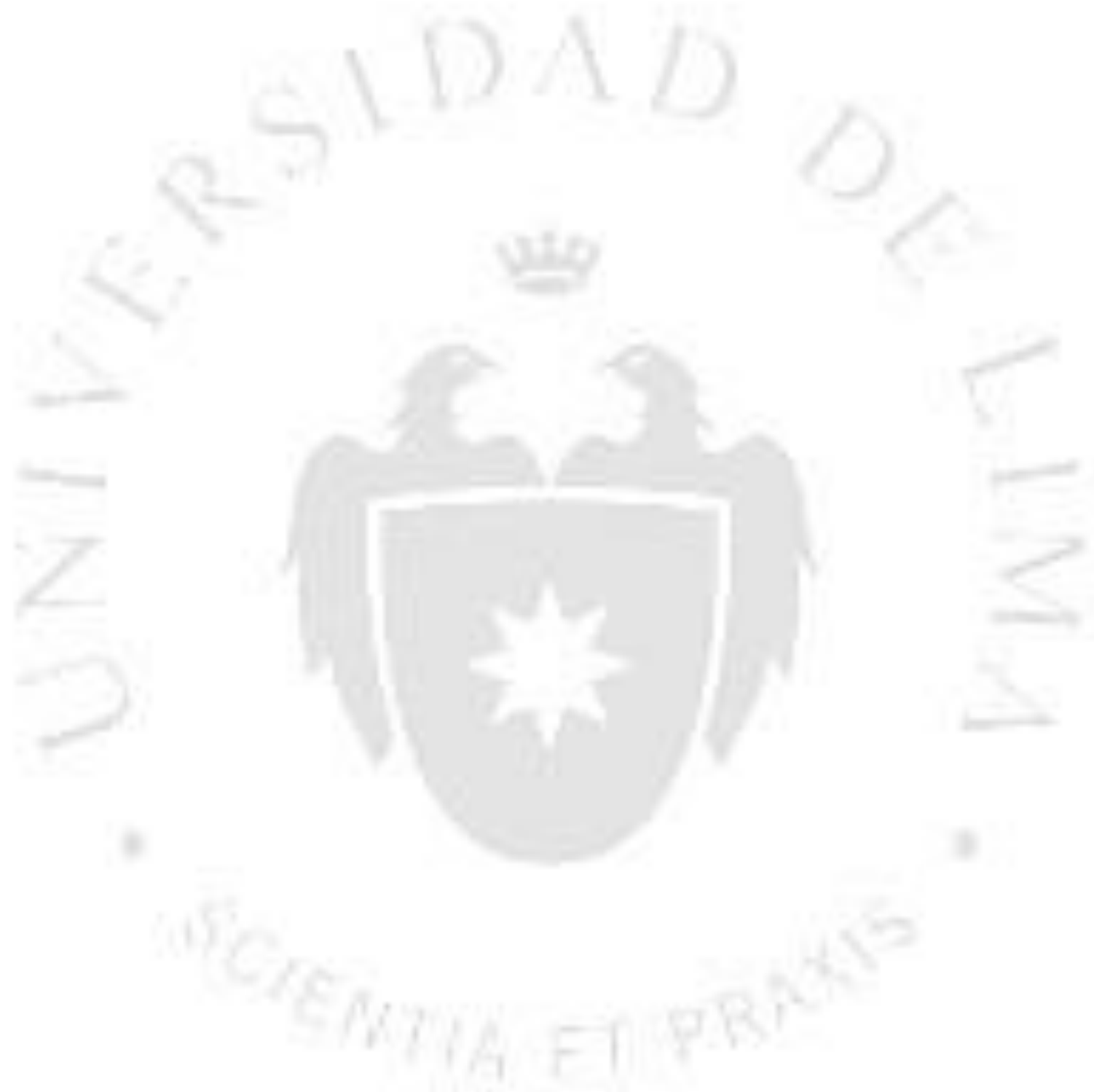




\section{BENEFICIOS LABORALES ESPECÍFICOS PARA LOS INTERNOS DE MEDICINA DEL PERÚ: PROPUESTA DE UN PROYECTO DE LEY}




\section{ÍNDICE}

INTRODUCCIÓN........................................................... 7

Esquema De Tesis.................................................................... 9

Método De Investigación - Marco Metodológico........................ 9

Tipo De Investigación ..................................................................... 9

Método De Análisis - Nivel De Investigación............................... 10

Procedimiento Y Desarrollo De La Investigación......................... 11

Planteamiento Del Problema........................................................... 11

Definición Del Problema................................................................ 12

Objetivo De La Investigación........................................................ 13

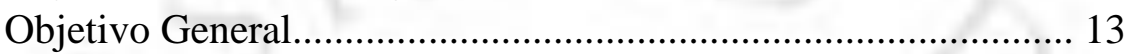

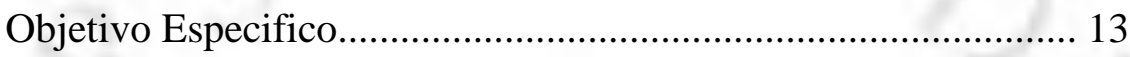

\section{CAPÍTULO I: PROGRAMA DE INTERNADO}

DE MEDICINA …………………………………………... 15

1.1 Funciones Y Deberes De Los Internos De Medicina...... 17

1.2 Sedes Hospitalarias - Hospitales Escuela......................... 20

1.3 Infraestructura Hospitalaria............................................. 21

1.4 Equipamiento Médico..................................................... 24

1.5 Mobiliario Clínico.............................................................. 25

1.6 Salud Ambiental Hospitalaria............................................. 26

1.7 Salud Ocupacional............................................................ 28

CAPÍTULO II: MARCO LEGAL_................................................. 31

2.1 MARCO LEGAL NACIONAL ......................................... 31

2.1.1 Ley $28515^{\circ}$ y D.S 007-2005 - Ley de modalidades formativas y su reglamento............... 32

2.1.2 D.S 003-2008 jornadas máximas de Modalidades formativas.......................................... 35

2.1.3 D.s 020-2002-EF Fijan Compensación para internos de medicina ....................................... 36

2.1.4 Reglamento del Comité Nacional de Pregrado de Salud-SINAPRES................................................... 37

2.1.5 Reglamento de internado medico en el Seguro social - EsSalud............................................. 40

2.1.6 Reglamento de seguridad y salud en el trabajo 42

2.1.7 Ley general de salud. 44 
2.2.1 Legislación Colombiana 47

2.2.2 Legislación Argentina............................................. 54

2.2.3 Legislación Chilena............................................. 58

\section{CAPÍTULO III: PROBLEMÁTICA DEL PROGRAMA DE} INTERNADO MÉDICO.

3.1 Principales problemas del programa de internado

Medico 63

3.1.1 Sobredemanda del campo medico 63

3.1.2 Horario excesivo de trabajo. 65

3.1.3 Sobrecarga laboral. .75

3.1.4 Inexistencia de ambientes para el descanso........... 78

3.1.5 Accidentes laborales. 81

3.2 Tipos de enfermedades e infecciones de transmisión en los hospitales escuela.

3.2.1 Métodos de prevención de transmisión enfermedades 84

A. Material de bioseguridad........................... 84

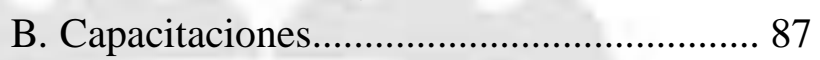

C. Vacunas. 90

D. Supervisión de labores.................................. 93

E. Seguro contra accidentes............................ 95

3.3 Beneficios del programa de internado medico.................... 98

3.3.1 Subvención económica.......................................... 98

3.3.2 Control de asistencia................................................ 101

3.3.3 Alimentación................................................................ 103

3.3.4 Conclusiones generales........................................... 105

CAPÍTULO IV: PROPUESTA DE UN PROYECTO DE LEY SOBRE BENEFICIOS LABORALES ESPECÍFICOS PARA LOS PRACTICANTES PRE PROFESIONALES EN SALUD. 107

4.1 Del seguro contra accidentes.. 108

4.2 De las capacitaciones 108

4.3 De la certificación de los hospitales escuela. 109

4.4 De la vacunación obligatoria a los internos de medicina... 110

4.5 Del horario de prácticas

4.6 Del seguro por responsabilidad civil. 112

4.7 De la alimentación. CONCLUSIONES 
REFERENCIAS.

116

BIBLIOGRAFÍA 


\section{$\underline{\text { Dedicatoria }}$}

A todas y cada una de las personas que creyeron en mí, inclusive cuando yo misma deje de hacerlo. 


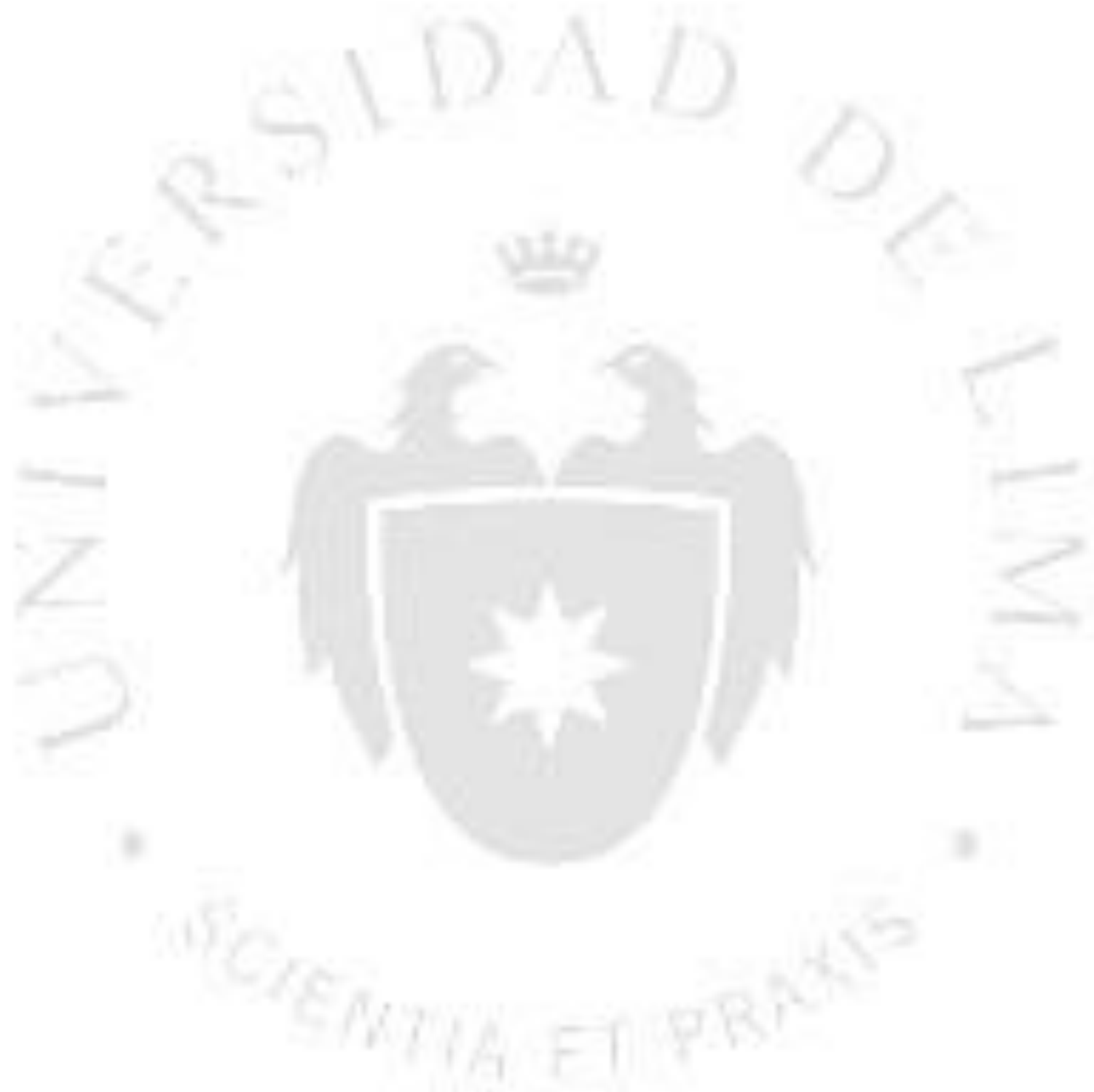




\section{INTRODUCCIÓN}

El programa de internado medico en el Perú, se encuentra destinado a capacitar a los estudiantes de último año de la carrera de medicina en la práctica hospitalaria y, de esa forma asegurar la correcta formación de los futuros médicos.

Sin embargo, dicho programa, principalmente en la ciudad de Lima, no cumple a cabalidad su razón de ser, ya que presenta serias deficiencias que perjudican tanto a las Instituciones a cargo de impartirlo, como a sus beneficiarios.

Esto se debe a que, en la mayoría de los Centros de salud que son designados como hospitales escuela, las instalaciones se encuentran en estado calamitoso. Además, no se imparte ningún tipo de capacitación en la práctica de la medicina, los ambientes destinados para la enseñanza teórica son poco adecuados, los derechos brindados a todos los practicantes son omitidos y negados a los internos de medicina, y no existe supervisión alguna de las labores desempeñadas, incrementando así el número de accidentes laborales. En suma, todo lo malo que se pueda imaginar sobre el programa de internado médico, pasa en los hospitales y les pasa a los internos peruanos. 
Por ello, la presente Tesis se centra en exponer las falencias del Internado, señalando cada uno de los aspectos que se deben mejorar, enumerando todos los dispositivos legales que regulan el tema y por ultimo presentando como resultado de toda la investigación realizada, una propuesta que sentará las bases para un proyecto de ley que otorgue beneficios específicos para los internos de medicina.

A lo largo de los cuatro capítulos con los que cuenta esta investigación lograre comprobar mi hipótesis al demostrar que el programa de internado medico es sumamente deficiente y de allí la necesidad de plantear una legislación acorde a las necesidades de estos profesionales. 


\section{ESQUEMA DE TESIS}

\section{Método de Investigación}

El método de investigación que desarrolle para probar mi hipótesis es el inductivo. Este consiste según (Behar Rivero, 2008) en crear leyes a partir de la observación de los hechos, mediante la generalización de un comportamiento observado; en realidad, lo que realiza es una especie de generalización, sin que por medio de la lógica pueda conseguir una demostración de las citadas leyes o conjunto de conclusiones". Por lo que tomare las normas existentes con respecto al tema y las analizare para demostrar que no son lo suficiente efectivas para cubrir con las necesidades de un grupo vulnerable de la población.

\section{Tipo de investigación}

Directamente ligado al método de investigación inductivo está la investigación cualitativa, que consiste en realizar entrevistas y encuestas, de manera que se puedan extraer experiencias y así plantear una solución al problema.

Para realizar las entrevistas abarqué población el total de practicantes pre profesionales de salud (internos de medicina) de la ciudad de Lima y como muestra seleccione un interno por cada hospital escuela. En algunos casos, participaron internos del mismo hospital, pero de diferentes años, para comprobar si el problema había sido 
solucionado o, en su defecto, se generó algún cambio en las condiciones. A esto, (Behar Rivero, 2008) le denomina muestreo intencionado, donde se selecciona los elementos que son representativos, lo que exige un conocimiento previo de la población que se investiga.

\section{Método de análisis}

Al ser un tipo de investigación cualitativa, se pueden utilizar varios métodos de análisis de la información recabada; en este caso utilizare el método de análisis interno, en el cual (Lopez Noguero, 2002) procura destacar el sentido y caracteres fundamentales de la información; asimismo, se centra en una interpretación personal y subjetiva

Así, de los testimonios de los internos de medicina plasmados en las entrevistas realizadas, resaltaré los principales problemas que afrontan al desarrollar sus prácticas pre profesionales y señalaré cuales son los puntos a mejorar.

\section{Nivel de investigación}

El nivel de investigación se refiere al grado de profundidad con que se aborda un objeto o fenómeno. Aquí (Arias Odón, 1999) indica si se trata de una investigación exploratoria, descriptiva o explicativa. El nivel de investigación que utilizaré será explicativo, que de acuerdo con (Arias Odón, 1999) se encarga de buscar el porqué de los hechos 
mediante el establecimiento de relaciones causa-efecto. Para este caso en concreto, desarrollaré los motivos de las fallas del programa de internado de medicina y cuáles son los elementos que las causan.

\section{Procedimiento y desarrollo de la investigación}

El desarrollo de la presente investigación será plasmado en cuatro etapas, la primera consistirá en definir que es un interno de medicina y cuáles son sus labores en un hospital escuela. Lo que nos llevará a la segunda etapa en la que se interpretaran las normas que velan por sus derechos y cuáles son los defectos de estas.

De esa manera, en la tercera etapa expondré los problemas que afrontan y plantearé las posibles soluciones, comparando nuestra legislación peruana con normas de tres distintos países de Latinoamérica para comprobar la importancia y necesidad de modificar los actuales decretos en torno al tema. Finalmente, en la cuarta etapa propondré sentar las bases para un proyecto de ley que brinde mejores derechos para los practicantes de medicina.

\section{Planteamiento del Problema:}

El programa de internado médico, no es como se describe en las normas, reglamentos y/o dispositivos que se encargan de regularlo; pues en la praxis, ni siquiera se cumple con los estándares mínimos que se 
Solicitan para una correcta enseñanza a los practicantes pre profesionales en salud.

El problema principal, es que no existe una correcta ni efectiva legislación que se ocupe de normar específicamente las prácticas pre profesionales en salud, que debido a su particular característica de desarrollarse en hospitales y de involucrar a terceros -pacientes-, no puede ser considerada como una práctica pre profesional más; tiene que ser regulada de manera específica. Es por eso que, la presente investigación se centra en establecer y sentar las bases para un proyecto de ley que brinde mejores beneficios laborales para los internos de medicina.

\section{Definición del problema}

¿Porque existe la necesidad de mayores beneficios laborales para los internos de medicina? ¿Que entendemos por beneficios laborales?

Dentro del programa de internado médico, se necesita de una mayor y mejor regulación de los derechos de los internos, ya que actualmente existen muchos problemas con la forma en la que se viene desarrollando el mencionado programa educativo. Ello, ha ocasionado diversas deficiencias tanto en la enseñanza teórica como en la práctica; generando así, un círculo vicioso en el que los hospitales y las 
universidades tienen mucho que ver; y en el que los internos y, sobre todo los pacientes, son los más afectados.

Es por eso que, del resultado de esta tesis, se pretende plantear alternativas de solución -que estarán plasmadas en el proyecto de ley con mayores beneficios laborales- que tengan como consecuencia la mejora del programa y por ende una mayor de protección a los usuarios de este.

\section{Objetivos generales y específicos}

\section{Objetivo general}

El objetivo general del presente trabajo es evaluar la situación actual del programa de internado médico y sentar las bases para un proyecto de ley que preste mejores y mayores beneficios laborales para los internos de medicina.

\section{$\underline{\text { Objetivos específicos }}$}

- Plantear que todos los internos de medicina tengan una póliza de seguro obligatorio contra accidentes de trabajo en el establecimiento de salud.

- Proponer que los internos de medicina cuenten con un seguro de vida opcional.

- Establecer que todos los centros hospitalarios en los que se brinde el programa de internado médico se encuentren 
obligatoriamente acreditados, para que de esa forma la enseñanza práctica sea uniforme.

- Recomendar que después de que los internos de medicina hayan cumplido con el horario de guardia nocturna no prosigan con el horario normal del internado y otorgarles un periodo de descanso.

- Procurar que se cree un fondo que cubra indemnizaciones por responsabilidad civil extracontractual por parte de los internos.

- Especificar cuáles serían las sanciones en los casos que los internos causen algún daño contra los pacientes (responsabilidad civil extracontractual)

- Gestionar que todos los internos de medicina antes de comenzar con el programa sean vacunados por los centros hospitalarios en los cuales vayan a realizar prácticas, contra cualquier tipo de enfermedad infectocontagiosa que pudieran contraer en el ejercicio de sus labores.

- Establecer capacitaciones obligatorias y periódicas en materia de bioseguridad, protocolo de atención de pacientes y manipulación de desechos biológicos. 


\section{CAPITULO I}

\section{Programa de Internado de medicina}

El programa de internado de medicina es la etapa en la que un estudiante de último año de la carrera de medicina desarrolla prácticas pre profesionales en un centro hospitalario (Hospital Escuela), con el fin de preparar4se en el ejercicio práctico de la medicina. El periodo de duración es 365 días (1 año) y podrá ser desempeñado en un solo hospital o hasta en cuatro, dependiendo del módulo que le toque cursar al interno de medicina. El programa de internado de medicina se caracteriza por ser a tiempo completo y de forma exclusiva (entrenamiento intensivo)

Asimismo, durante el transcurso de los doce meses de duración se llevarán a cabo cuatro módulos de enseñanza distintos, los mismos que estarán divididos en tres meses cada uno (medicina general, cirugía 
general, obstetricia/ginecología y pediatría) y el orden de las rotaciones dependerá de la(s) sede(s) hospitalaria(os) a la que los internos asistan. De la misma manera, el lugar de prácticas será asignado con anterioridad al inicio del internado, que dependerá directamente del rendimiento del alumno durante el transcurso de la carrera de medicina. Ello se debe a que, los alumnos con mejor promedio académico tendrán prioridad al escoger en que hospital o hospitales desean desempeñar sus prácticas pre profesionales.

Posterior a ello, una vez designado el hospital escuela, se empezará con el programa de internado médico como todos los años el 01 de enero. Según los distintos reglamentos de internado médico de las distintas facultades de medicina del país, el primer día de inicio del programa estará designado a una breve introducción de las labores que los internos deberán realizar, así como a una capacitación por parte de los médicos residentes. Estas capacitaciones, de acuerdo al reglamento deberán dictarse regularmente durante el período de internado-

Por otro lado, las actividades que se realizarán en las sedes hospitalarias variarán entre unas y otras, pero básicamente se limitarán a servicios de hospitalización, consultorios externos, servicios o departamento de emergencia y atención primaria de Salud. De la misma forma se impartirán actividades académicas como charlas y 
capacitaciones a cargo de los médicos residentes con el objetivo de complementar la enseñanza práctica brindada en el Hospital.

Así, el programa de Internado se llevará a cabo en sedes completamente equipadas con las áreas y materiales necesarios para una adecuada preparación de los internos de medicina que les permita estar lo suficientemente preparados para afrontar las exigencias de la carrera médica.

\section{$\underline{\text { Los internos de Medicina }}$}

Un interno de medicina, es aquel estudiante de medicina que culmino satisfactoriamente el sexto año de la carrera y al que le corresponde iniciar el programa de internado obligatorio para obtener el grado de Médico cirujano.

\subsection{Funciones y deberes de los internos de medicina}

Dentro de las funciones que los internos deberán ejecutar, se encuentran las siguientes: recepcionar al paciente en la sala de emergencias $\mathrm{y}$ realizar los procedimientos necesarios para hospitalizarlos, practicar los exámenes primarios correspondientes como toma de presión, muestras de (sangre, orina, heces, punciones, biopsias, etc.), además de revisión general del enfermo. 
Igualmente, se le pondrá a cargo de, por lo menos, 10 camas o 15 como máximo (esto dependerá del hospital y de los pacientes internados diariamente, el número se puede incrementar entre una y otra sede). Además, tendrán como tarea elaborar la historia clínica de los pacientes, así como llegar a establecer un posible diagnostico que será confirmado o desestimado cuando el médico residente realice su ronda de revisión.

En los casos que sean necesarios, el interno acompañara al paciente a sala de cirugía y entregará toda la documentación pertinente al médico que efectuara la intervención quirúrgica. Por otra parte, previo a ello, llevará al paciente a realizarse los exámenes especiales (tomografía, ecografía, rayos x, etc.) que sean solicitados y supervisará su correcta ejecución. A la vez, tendrán la obligación de realizar las rondas de supervisión en conjunto con el Jefe de Servicio o aquellas que sean programadas por el responsable o coordinador de rotación.

Por otro lado, todos los internos tendrán que portar los distintivos oficiales de manera obligatoria y encontrarse correctamente uniformados; de igual forma, registrarán su asistencia diaria en las hojas de control $\mathrm{o}$ en el sistema que tenga implementado el centro hospitalario. El interno permanecerá en las instalaciones del Hospital en todo momento, no pudiendo apartarse de sus funciones hasta que se le indique lo contrario. En caso extremo de no poder continuar con las 
labores diarias, de ser necesario pedirá permiso al encargado del programa de internado para poder retirarse antes de que termine su turno.

De igual forma, Los internos de medicina cumplirán con las guardias nocturnas y diurnas que se les asignen; en el caso de no poder acudir, siempre informará al médico encargado de la supervisión de internos.

Todos los internos contarán con la oportunidad de observar a los médicos residentes y tratantes realizar intervenciones quirúrgicas en sala. Todo ello, con el fin de que puedan expandir sus conocimientos; en algunas oportunidades, los practicantes podrán asistir en los procedimientos y así poder practicar las enseñanzas adquiridas, siempre bajo la estricta supervisión del médico encargado.

Recíprocamente, el tiempo de los internos de medicina será divido también entre la práctica pre profesional y las charlas académicas dentro del centro hospitalario. Según los reglamentos del programa de internado, y como mencione anteriormente, se deberán impartir capacitaciones alternadas con los módulos en los que se encuentren los internos. Igualmente, se llevarán a cabo mesas redondas en las que se podrá debatir con los médicos residentes sobre casos médicos especiales: así como, conversatorios clínicos, quirúrgicos y patológicos. 
Para concluir, se les pedirá a los internos la asistencia a distintos seminarios de acuerdo a las rotaciones en la que se encuentren. Todo esto, con el fin de mejorar el desempeño de los internos durante la práctica pre profesional. Eventualmente, se les tomarán prácticas y se les asignarán monografías, las que serán controladas por el responsable de la Sede representante del Director de Internado ante la Sede Hospitalaria.

\subsection{Sedes Hospitalarias - Hospitales Escuela}

Actualmente en el Perú, la atención de los servicios de salud está divida en 3 grandes ramas. En el primero, se encuentran los hospitales dirigidos por el Ministerio de Salud (MINSA); el segundo, lo componen los hospitales dirigidos por el sistema de seguro social (ESSALUD), que jerárquicamente le pertenecen al Ministerio de Trabajo (MTPE); el tercero corresponde a los hospitales de sanidades dirigidos por la Policía Nacional del Perú (PNP) y Fuerzas Armadas (FF. AA). De los cuales 147 le pertenecen al primero, 79 al segundo y 21 al último.

En todos ellos, los internos de medicina realizan prácticas pre profesionales; por lo que, estos deberían tener las condiciones necesarias para albergar los más de 9 mil estudiantes de medicina en todo el Perú cada año. 
Bajo esta perspectiva, analizaré la Infraestructura, el equipamiento, y la salud ambiental hospitalaria, con el fin de exponer las ínfimas condiciones en las que los internos de medicina tienen que realizar prácticas.

\subsection{Infraestructura Hospitalaria}

En el último informe del Ministerio de Salud, Diagnostico Físico Funcional "Plan Hospitalario Integral" que, entre otros puntos expone las condiciones de los Hospitales, con énfasis en la infraestructura de las edificaciones en las que se encuentran los mismos; podemos evidenciar la falta de espacios destinados únicamente para la enseñanza de los internos, así como la escasez de camas para que estos pernocten durante el cumplimiento de las horas de guardia nocturna.

Es ampliamente conocido que las instalaciones de la mayoría de los hospitales en el Perú se encuentran en deplorables condiciones no aptas para la atención médica- pero que siguen funcionando debido a la gran demanda y al poco número de instituciones. Asimismo, el (Ministerio de Salud, 2006) concluye que a nivel nacional 32 de los llamados "hospitales" no reúnen la cartera de servicios para un nivel II y III de atención de la salud. 
A esto se suma la antigüedad de los centros médicos, pues el 23\% de los hospitales tienen de 51 a más de 100 años, el 37\% menos de 25 años y el mayor porcentaje corresponde a aquellos entre 26 a 50 años con $40 \%$. Por ejemplo, uno de los Hospitales con mayor demanda, el Hospital Dos de Mayo tiene más de 136 años de antigüedad.

En estos Hospitales, no se ha realizado ningún cambio en los últimos años que permita adecuarlos al crecimiento de la población y, consecuentemente, al aumento del número de emergencias y consultas que conlleva este incremento. Otro aspecto importante es la tenencia legal de la propiedad, encontrándose que los mencionados hospitales, como el (Ministerio de Salud, 2006) señala, aún están en diversas etapas de regularización de su inscripción en los registros de propiedad del inmueble, lo que impide realizar inversiones de mejoramiento de la infraestructura.

Lo que ha llevado a las universidades a "implementar" ambientes destinados a la docencia universitaria en espacios libres que toda edificación debe de tener; ello, sin ningún respaldo legal. Según entrevistas realizadas para esta tesis, se pudo conocer que los referidos ambientes, muchas veces son construidos con contrachapado, y debido a las características de este material los ruidos externos son fácilmente filtrados en el área, no permitiendo así una adecuada concentración de 
los internos de medicina, principales y casi únicos usuarios de estos espacios, lo que resulta en un déficit en la calidad de enseñanza.

Continuando con el origen de la falta de remodelación de la infraestructura hospitalaria del (Ministerio de Salud, 2006), se puede mencionar que, por ejemplo, solo 28 establecimientos cuentan con declaratoria de fábrica inscrita y saneada, mientras 35 establecimientos en proceso de inscripción de la declaratoria de fábrica. En cuanto a la propiedad del terreno, 61 se encuentran registrados y 23 en proceso de inscripción. Asimismo, un promedio de 17 hospitales se encuentra en calidad de "prestados" al Ministerio de Salud y la propiedad se encuentra a nombre de distintas instituciones benéficas, entre ellos los Hospitales Arzobispo Loayza, San Bartolomé, Instituto Materno Perinatal, Hermilio Valdizán, Hipólito Unánue y otros.

Esta situación se recrudece aún más en las provincias. En la región Huánuco más del $50 \%$ de los ambientes se encuentran inoperativos, lo mismo sucede en la Región Ucayali, Arequipa y Junín que inclusive, representan mayor porcentaje de inoperatividad. 
Evidentemente, las condiciones en las que los internos de medicina deben desarrollar sus prácticas son lamentables, además de la infraestructura, los equipos médicos no se encuentran aptos para su manipulación.

\subsection{Equipamiento Médico:}

El equipamiento médico es parte de la tecnología que a lo largo de los años él (Ministerio de Salud, 2006) ha logrado obtener con diversas estrategias. Actualmente se considera que la tecnología debe ser evaluada, aceptada e incorporada, además de ser necesaria su administración y planificación para su sustitución oportuna.

Sin lugar a dudas, el equipamiento médico es pieza

fundamental de todo Hospital; por lo que, estos deben de estar en óptimas condiciones que les permitan un completo funcionamiento diario y constante. Este debe de ser clasificado en cinco categorías para su correcta distribución; Mobiliario Clínico y Administrativo, Equipo Biomédico, Electromecánico, de Limpieza - Esterilización y Equipos varios. 
Para los fines de la presente investigación solo me concentraré en tres categorías, debido a que, son las únicas utilizadas por los internos de medicina; estas son: Equipo de Mobiliario Clínico, Equipo Biomédico y Equipo de Esterilización.

\subsection{Mobiliario Clínico}

Conforme al último informe de Condiciones Hospitalarias del (Ministerio de Salud, 2006) se dio a conocer que el $45 \%$ del mobiliario médico se encuentra en condiciones aceptables de funcionamiento, el $25 \%$ requiere ser reemplazado y el $8 \%$ debe ser reparado

\footnotetext{
A la vez, el mobiliario médico se encuentra clasificado en tres rubros (equipamiento biomédico, laboratorio y esterilización) encontrándose el $57.47 \%$ en buen estado de funcionamiento, el $34.30 \%$ requiriendo reemplazo y el $8.23 \%$ necesita reparación.
}

Entre el $50 \%$ y $60 \%$ del equipo de laboratorio se encuentra en condiciones aceptables, mientras que el resto debe ser reemplazado aun estando operativo, por motivos de avance tecnológico. La misma situación ocurre con el equipamiento biomédico (soporte de vida, ayuda al diagnóstico, laboratorio, etc.) y el de esterilización. 
En cuanto al grado de deterioro físico y obsolescencia de los equipos; por ejemplo, tenemos que sólo un 59\% está operativo, de ese porcentaje el 33\% requiere ser reemplazado, y el $8 \%$ debe ser reparado. Esta pérdida sistemática de la capacidad instalada del volumen de servicios repercute en la disminución tanto de la cobertura como de la calidad de sus servicios de salud.

A grandes rasgos, ello significa que más de la mitad de los equipos no funcionan y la parte restante no sirve de mucho, ya que no cumple con las necesidades de los usuarios pues tecnológicamente no son lo suficiente avanzados. Es así que una vez más se comprueba que la calidad de condiciones en las que los internos de medicina tienen que aprenden su labor y en la que los pacientes deben de atenderse, es mucho más que deficiente, colinda con lo deplorable.

\subsection{Salud Ambiental Hospitalaria}

Dentro de la categoría de salud ambiental hospitalaria, se encuentran 3 grandes rubros: calidad de agua de consumo, manejo y disposición de aguas residuales, y residuos sólidos hospitalarios. 
De acuerdo a los informes obtenidos del Ministerio de Salud, se llegó a concluir que en los rubros de calidad de agua de consumo y disposición de aguas residuales, las condiciones de su manejo no son del todo óptimas. Sin embargo, estas son controladas de manera eficiente en un porcentaje mayor al $80 \%$, por lo que no generan ningún inconveniente ni a los pacientes ni a los trabajadores.

En realidad, el problema se encuentra en el manejo y disposición de los residuos solido hospitalarios. Conforme lo indica (Ministerio de Salud, 2006) estos se generan en los establecimientos de salud, producto de las actividades asistenciales. Ello se debe a que, si en circunstancias no deseadas, la carga microbiana que contienen los residuos biocontaminados o residuos especiales ingresan mediante vía respiratoria, digestiva o dérmica, al organismo humano, causarían severos daños en la salud de las personas.

Por lo tanto, estos residuos deben ser correctamente manejados y trasladados a plantas de tratamiento especiales. No obstante, solo existen 5 plantas en todo el Perú que están exclusivamente destinadas para hospitales 5 Hospitales (Hospital Hipólito Unánue, Hospital Regional del Cusco, Hospital Regional de Loreto, Hospital Regional de Trujillo y el Instituto Nacional del Niño de San Borja). 
Asimismo, como lo describe el portal (Proexpansion, 2014) un 70\% de los Hospitales en todo el Perú no realiza ningún tratamiento de residuos sólidos. Por lo que, estos residuos terminan en botaderos informales a merced de recicladores que recogen, lavan y re venden productos que no son reciclables.

Este es el caso de la empresa Global Servicio Integral Médica S.A, encargada del traslado de residuos biomédicos y de su tratamiento, que no cumplía con la función por la que se le pagaba y botaba los residuos en las riberas del Río Chillón. Así, que se puede concluir que el tratamiento de los residuos biomédicos en los distintos hospitales de Lima no es el más óptimo ni el más adecuado.

Sin embargo, desde finales del 2014 se creó la primera planta de tratamiento de residuos, que estará encargada de disponer de los desechos de más de 3.500 establecimientos de Salud de todo Lima. Entre tanto, esta situación no varía para los demás Hospitales de las distintas regiones del país, que continúan disponiendo de los residuos médicos de formas insalubres. 


\subsection{Salud ocupacional:}

Por último, pero no menos importante, se encuentra el rubro de la Salud Ocupacional, que se dedica a controlar los accidentes que ocurren en los centros laborales. En el caso de los Hospitales y Clínicas, los accidentes laborales son mucho más preocupantes, puesto que la mayoría de trabajadores se encuentra en contacto constante con objetos punzo cortantes, material biomédico contaminado y sustancias toxicas.

De acuerdo a entrevistas realizadas a internos de medicina, ellos son los más propensos a sufrir de estos accidentes, ya que no cuentan con ningún control ni supervisión la mayoría de las veces en las que ejecutan cualquier procedimiento que requiera del uso de material médico punzo cortante. De hecho, cada uno de los entrevistados ha sufrido o ha visto accidentes con agujas y escalpelos.

Todo esto se corrobora también con las estadísticas obtenidas por el Ministerio de Salud, en donde se menciona que el $43 \%$ de accidentes laborales son heridas en las manos ocasionadas por objetos punzo cortantes. Sin embargo, no se menciona cual es el porcentaje de accidentes ocasionados por el derrame de fluidos corporales de pacientes (sangre, orines, etc.), que, según las entrevistas realizadas, son incidentes que ocurren con gran frecuencia. 
Entonces, podemos concluir que el riesgo de accidentes se incrementaría si es que los centros de salud no cuentan con los estándares mínimos de cuidado. Asimismo, se debe de capacitar a todo el personal a través de charlas que por lo descrito anteriormente no se llevan a cabo.

\section{Conclusiones:}

Por todo lo señalado y descrito anteriormente, podemos concluir que si no existen los recursos, ni la infraestructura, ni el control y mucho menos la posibilidad de que estos se consigan ¿cómo podrán los internos de medicina desarrollar habilidades y adquirir la experiencia requerida que los ayudara en los subsiguientes años en que ejercerán su profesión? Este, es sin duda el principal punto en el que se debe incidir para mejorar las condiciones laborales de no solo los internos de medicina, sino de todos los trabajadores del sector salud en el Perú. 


\section{CAPITULO II}

\section{MARCO LEGAL}

En este capítulo haré referencia a todas las normas que regulan sobre el programa de internado, que en su mayoría son reglamentos y decretos. Asimismo, comparare nuestra legislación con jurisprudencia latinoamericana, y de esa manera poder sustentar mi propuesta de una mejor y más específica legislación que se encargue de las necesidades de los internos de medicina.

\subsection{MARCO LEGAL NACIONAL}

Actualmente, la normativa referente al programa de internado médico no es lo suficientemente específica como para solucionar todos los problemas que aquejan a este sector. $\mathrm{Y}$ es que, dentro del marco 
legal nacional, solo existe un Decreto Supremo, el mismo que no sirve de mucho para mejorar las circunstancias que afrontan diariamente los practicantes pre profesionales de medicina.

Por ello, realizaré un análisis de cada una de las leyes que hacen alguna o poca referencia sobre el tema en cuestión y señalaré cuáles son los puntos a favor y en contra. Asimismo, indicaré que debería cambiarse para garantizar una mejor cobertura de los derechos de los internos y qué debería eliminarse por ir en contra de otras normas.

\subsubsection{Ley $\mathbf{N}^{\circ} 28518$ sobre modalidades formativas y el}

\section{Decreto Supremo $N^{\circ}$ 007-2005-TR: Reglamento}

\section{de La Ley $\mathbf{N}^{\circ} 28518$ sobre modalidades}

\section{formativas}

Como dicta la norma en mención, en su artículo $1^{\circ}$ "Las modalidades formativas son tipos especiales de convenios que relacionan el aprendizaje teórico y práctico mediante el desempeño de tarea programadas de capacitación y formación profesional”, y en efecto lo hacen. También se señala que no se encuentran regidas por la normativa laboral vigente, lo que significa que no existe ninguna relación laboral entre la empresa y el practicante o aprendiz, sino que existe un convenio de prácticas donde los estudiantes universitarios -la 
mayoría- podrán practicar, valga la redundancia, lo aprendido y de esa forma prepararse para su vida profesional.

Lo descrito anteriormente, como lo señala la (Ley $\mathrm{N}^{\circ} 28518$, 2005, Art. 8) se efectuará mediante la ejecución de tareas productivas correspondientes a un Plan específico de Aprendizaje; de igual manera, se deberá brindar capacitación constante a los beneficiarios de este programa para que desempeñen una mejor labor y más eficiente. Así también se deberá pagar puntualmente la subvención mensual acordada, concedérseles el descanso semanal y feriados no laborables.

De acuerdo al reglamento que regula sobre las modalidades formativas, que se encarga de normar sobre los deberes y derechos de los distintos tipos de convenios entre una empresa y sus practicantes, en su artículo $\mathrm{N}^{\circ}$ 5; se precisa que, los estudiantes universitarios de cualquier carrera que deseen realizar prácticas y así reforzar lo aprendido en las aulas, se hallan bajo la modalidad de aprendizaje con predominio en el centro de formación profesional (prácticas pre profesionales), que es el caso de los estudiantes de medicina.

Según la norma, los practicantes pre profesionales tienen como derecho a un horario de refrigerio que debe ser otorgado en las mismas condiciones en las que se le es concedido a los demás trabajadores de la empresa; asimismo, se les debe de otorgar una subvención económica 
que no puede ser menor a la establecida por la Ley; es decir no menor a la Remuneración Mínima Vital. De igual forma, se les deberá de otorgar el pago de una subvención económica adicional por cada 06 meses laborados.

En cuanto a la seguridad que las empresas deben de otorgar a los practicantes, se encuentra lo mencionado en el artículo $59^{\circ}$, que nos dice que se deberá proporcionar todo tipo de equipamiento de protección que sea necesario y acorde a las labores realizadas. Conforme a ello, la empresa también deberá contratar un seguro a favor del practicante pre profesional.

Todo lo mencionado anteriormente, es lo que debe de brindar cualquier empresa o institución que desee contar un practicante pre profesional. Sin embargo, para el caso de los practicantes de medicina, la Ley y el reglamento no se cumple. Según las entrevistas realizadas a diversos internos de medicina (Ver. Anexo $\mathrm{N}^{\circ} 1$ ). La mayoría no cuenta con un seguro otorgado por el centro hospitalario donde labora, las horas de refrigerio no son las adecuadas y el ambiente donde deben de tomarlo mucho menos. De la misma forma, muchos de ellos no perciben la subvención económica que por Ley les corresponde, o en el caso que la reciban es menor a una remuneración mínima vital, que también va en contra de lo señalado por el reglamento. Por otra parte, 
los internos tampoco reciben materiales que les permitan protegerse ante accidentes que puedan ocurrir en el desarrollo de sus labores.

Sin duda, la Ley y el reglamento cubren las necesidades básicas que un practicante pre profesional necesita, pero no cubren las necesidades específicas de los internos de medicina, ya que están orientadas a normar sobre todas las carreras y no una en especial. Por lo que, tratar de modificarla no solucionaría el problema. Lo que se debe buscar, es crear nueva legislación orientada directamente a proteger los derechos de los internos de medicina humana.

\subsubsection{Decreto Supremo 003-2008-TR Dictan medidas}

sobre jornadas máximas de

modalidades formativas reguladas por la Ley

\section{$\mathbf{N}^{\circ} \mathbf{2 8 5 1 8}$}

\section{internado en ciencias de la salud.}

Conforme con lo dispuesto por el Decreto Supremo, los internos de medicina tendrán como jornada máxima 06 horas diarias, 36 semanales y 150 mensuales. Asimismo, deberán de otorgársele 05 horas de descanso antes de cada guardia; sin embargo, esto no se da en la práctica. Los horarios en los que desempeñan sus laborales varían entre las 12 y 15 horas diarias sin descanso antes o después de cada guardia, muchas veces sin la supervisión de un médico encargado. También cabe 
acotar, que los internos de medicina laboran de lunes a domingo y que no tener horas apropiadas de descanso repercute directamente en su desempeño y en el alza de accidentes laborales.

No obstante, las horas establecidas para el desempeño de las labores diarias por dicho decreto no son las suficientes para adquirir la experiencia necesaria y las horas laboradas en efecto son demasiado excesivas; por lo que, un balance entre las dos sería lo más adecuado y de esa forma garantizar un cumplimiento adecuado de las funciones que los internos realizan, además de brindar un servicio de salud decente a los pacientes que acuden a los centros hospitalarios.

\subsubsection{Decreto $\quad$ Supremo $\quad N^{\circ} \quad$ 020-2002-EF Fijan} compensación remunerativa mensual

para internos de Medicina Humana y

\section{Odontología}

Este decreto supremo, fue uno de los pocos que reguló sobre los beneficios de los internos de medicina específicamente. Según este, se buscaba mejorar los ingresos mensuales, aumentando la subvención a S/.400.00 nuevos soles; ya que, anteriormente recibían S/.200.00 nuevos soles de acuerdo con el Decreto Supremo $\mathrm{N}^{\circ} 12-94-E F$. Esta suma para la época, cuando la remuneración mínima vital era de 
S/.410.00 nuevos soles, era satisfactoria para los internos. Sin embargo, ahora después de más de 12 años, la suma francamente resulta irrisoria.

Como describí en los párrafos anteriores, la Ley de modalidades formativas indica que la subvención mensual para los beneficiarios de esta, no debe ser menor a una remuneración mínima vital y su primera disposición transitoria y final, nos dice "Deróguense (...) las demás normas que se opongan a lo dispuesto en la presente Ley”, y es evidente que, el Decreto Supremo N 020-2002-EF lo hace.

No obstante, actualmente los internos de medicina vienen recibiendo dicho monto $-\mathrm{S} / .400 .00$ nuevos soles- que no les ayuda a costear los gastos en los que incurren para trasladarse a los centros de salud, que muchas veces se ubican lejos de sus domicilios; y mucho menos les alcanza para cubrir otros gastos en los que deben de incurrir, como alimentación y vestimenta.

Entonces, me pregunto ¿Por qué aún siguen percibiendo un monto menor al acordado? La respuesta es clara. Ningún legislador se ha preocupado realmente por normar ni correcta ni específicamente sobre los derechos y deberes de los internos de medicina. 


\subsubsection{Reglamento del Comité Nacional de Pregrado de Salud del SINAPRES}

Él (Reglamento del Comité Nacional de Pregrado en Salud del SINAPRES, 2006, Art.1) se encarga de establecer el proceso de integración docencia - servicio de investigación en pregrado entre las universidades y los centros de salud. Básicamente, nos indica quienes son los encargados de la supervisión del correcto desarrollo de las actividades de los internos de medicina en los centros de salud y cuáles son los deberes de los beneficiarios del programa de internado.

De acuerdo a la estructura del SINAPRES, este se conforma por el Comité Nacional de Pregrado en Salud, Los Comités Regionales de Pregrado en Salud y Los Subcomités de Sedes Docentes o Redes de Servicios de Salud.

El primero, (Reglamento del Comité Nacional de Pregrado en Salud del SINAPRES, 2006, 1era disposición complementaria) es la máxima instancia en el caso de que se necesitará resolver sobre aquellas situaciones no contempladas expresamente en las normas del Sistema, así como las presuntas ambigüedades que pudieran presentarse. A su vez es el encargado en la ciudad de Lima, de velar por la seguridad e integridad de los integrantes del programa de internado. 
Fundamentalmente, cualquier incidencia, problema y formas en la que se desarrolla el Programa de Internado deberá ser resuelto por dicho Comité. Asimismo, él (Reglamento del Comité Nacional de Pregrado en Salud del SINAPRES, 2006, Art 21) está encargado además de brindar las facilidades para la formación de estudiantes, cautelando los derechos de los pacientes y la adecuada prestación del servicio, así como aplicar las normas y procedimientos de bioseguridad pertinentes, y proveer a los internos los medios necesarios para su bioprotección.

Sin embargo, a pesar de velar por la integridad de los estudiantes de medicina (internos). Este reglamento les exige, según el artículo $23^{\circ}$ inciso D) del Reglamento del Comité Nacional de Pregrado de Salud del SINAPRES “contar con seguro de salud, el cual será se exigido como requisito para su ingreso a los establecimientos de salud (...)”. Lo que, en mi opinión, va en contra de la función que dicen desempeñar, dicho requisito debería ser exigido a los centros de salud; ya que, ellos son los tendrían que otorgar un seguro a los estudiantes, conforme a lo mencionado por el artículo $41^{\circ}$ inciso 8) de la Ley sobre modalidades formativas.

Por otro lado, como describí anteriormente y como pude concluir de las entrevistas realizadas a distintos internos de medicina de los varios centros de salud en los cuales se lleva a cabo el programa de 
internado de medicina, no se cuenta con elementos de protección de bioseguridad ni se imparten charlas o se capacitan adecuadamente a los practicantes para prevenir cualquier tipo de contagio de enfermedades.

Así las cosas, puedo determinar que el Comité del SINAPRES, en realidad no protege de forma adecuada el desarrollo del proceso de integración docencia y servicio entre los hospitales, universidades e internos de medicina. Solo cumple la función de ente integrador de las distintas direcciones del Ministerio de Salud, representantes de Universidades y representantes de los estudiantes de medicina.

\subsubsection{Reglamento de Internado Médico en el Seguro}

\section{Social de Salud - ESSALUD}

El Reglamento de Internado Médico en EsSalud, se encuentra contemplado en la Resolución de Gerencia General $\mathrm{N}^{\circ}$ 425GGESSALUD-2007, que norma sobre la convocatoria y selección de internos; así como, la acreditación de hospitales escuela y la suscripción de convenios de práctica pre profesional, siendo su función más importante que tiene este reglamento es la de regular acerca de la modalidad de trabajo del interno de medicina humana. 
Acorde a ello, se especifica en el artículo $17^{\circ}$ que, el Internado de medicina es a tiempo completo con una duración de 365 días y con un horario de trabajo de 08 horas diarias como mínimo. Asimismo, conforme al artículo $19^{\circ}$, tiene la responsabilidad de asignar las funciones que desarrollarán los internos, las cuales van desde interrogar al paciente sobre sus síntomas, formulación de diagnóstico y tratamiento, participar de intervenciones quirúrgicas, hasta brindar una adecuada atención a las personas que acuden a atenderse en el horario de guardia nocturna.

Por otro lado, en el artículo $20^{\circ}$, se detallan cuáles son los derechos de los internos de medicina; tales como, recibir alimentación y brindarles facilidades para su alojamiento a la hora de realizar guardias, otorgarles mandiles y contar con un seguro contra riesgos. De igual manera, se señalan las funciones que tienen los docentes; más allá de enseñarles, deberán evaluar periódicamente el desempeño de sus alumnos -internos- además de asesorarlos y supervísalos en todas las actividades que desempeñen.

Todo ello, lamentablemente no se cumple en la realidad. Ni los internos trabajaban como mínimo 08 horas diarias -las horas laboradas promedio diariamente son 12- ni se les otorgan mandiles, ni se les brindan alimentos durante el horario "normal" de sus funciones y mucho menos durante las guardias. 
Por otra parte, en cuanto a las medidas disciplinarias impuestas a los internos de medicina, estas irán desde una amonestación verbal, amonestación escrita, suspensión, hasta la conclusión del convenio de prácticas, que considero, se encuentran bien orientadas y acordes con las faltas que los practicantes pudieran cometer.

Entonces, si bien es cierto, la intención del reglamento es otorgar mejoras en la calidad del programa de internado médico, todo queda en propósitos y expectativas que no se llega a cumplir.

\subsubsection{Reglamento de Seguridad y Salud en el Trabajo}

\section{- Decreto Supremo No009-2005-TR}

El reglamento de Seguridad y Salud en el trabajo, está destinado a normar sobre la adecuada protección que deben brindar los empleadores a sus trabajadores. Si bien es cierto, los internos de medicina no son reconocidos como trabajadores de los Hospitales, de todas maneras, estas Instituciones les deben brindar ambientes y condiciones que no dañen su salud ni física ni mentalmente. A continuación, haré un análisis de las normas que se deberían de cumplir.

En principio, toda Institución debe de contar con medidas que permitan prevenir accidentes laborales. La mejor forma de hacerlo, es a través de la capacitación de los trabajadores; estos tienen que recibir 
charlas, capacitaciones y/o asesorías en cuanto a la forma de desarrollar sus labores, de esta manera ya se estará reduciendo de manera significativa el nivel de accidentes que se podrían producir en los centros laborales.

De la misma forma, facilitar a todos los trabajadores con equipos y materiales de protección personal adecuados, asegurándose que se utilicen permanentemente. En el caso de los internos de medicina, el material de protección que se les debe de brindar son mandiles, guantes quirúrgicos, batas, tapa bocas y gorras y botas quirúrgicas.

Igualmente, el empleador -los centros hospitalarios- tendrán que contar con infraestructura adecuada que permita laborar adecuadamente tanto a los internos como a los demás trabajadores; para el caso en concreto, en mi opinión, contar además con ambientes destinados solo para el uso de los internos y su correspondiente descanso después de las guardias.

Sin embargo, después de entrevistar a varios internos de distintos Hospitales escuela, confirmé que no se les entrega ninguno de los materiales de protección descritos anteriormente y que, además, los practicantes deben de conseguirlos por sus propios medios; así como, tampoco existe un lugar de descanso para los internos y las infraestructuras de los Hospitales se encuentran en estado calamitoso. 
Lo más grave, es que no reciben capacitación alguna o en el mejor de los casos reciben una sola capacitación en todo el lapso de tiempo que dura el programa de internado.

Como se puede apreciar, no se cumplen con los estándares mínimos requeridos por La Ley y el Reglamento de Seguridad en el Trabajo, que más que necesarios son indispensables sobre todo en los Hospitales que son lugares mucho más propensos a tener una alta tasa de accidentes laborales debido a la manipulación de sustancias y de objetos punzo cortantes.

\subsubsection{Ley General de Salud - Ley $\mathbf{N}^{\circ} \mathbf{2 6 8 4 2}$}

La Ley General de Salud, está destinada a regular sobre la protección de la salud de todos los ciudadanos peruanos y cuál es la forma en la que los centros hospitalarios deben brindar atención médica. Conforme a ello, todos los establecimientos de salud deben de cumplir con un mínimo de requerimientos, como contar con equipamiento, personal asistencial, sistemas de saneamiento y control de riesgos.

Además de ello, la norma establece entre otros puntos; cuales son los productos farmacéuticos que se pueden usar para recetar a un paciente, la forma en la que se utilizan los equipos médicos y quirúrgicos, de la higiene y seguridad en los ambientes de 
trabajo, etc. Pero lo que mayor relación tiene con la función que desempeñan los internos, es el tema de las sanciones que se imponen tanto a los establecimientos de salud como al servicio médico en caso de ser responsables por los daños y perjuicios que se les ocasiones a los pacientes.

Según el artículo 48 de la presente Ley, "El establecimiento de salud o servicio médico de apoyo es solidariamente responsable por los daños y perjuicios que se ocasionan al paciente, derivados del ejercicio negligente imprudente $\mathrm{o}$ imperito de las actividades de los profesionales, técnicos o auxiliares que se desempeñan en éste con relación de dependencia. Es exclusivamente responsable por los daños $\mathrm{y}$ perjuicios que se ocasionan al paciente por no haber dispuesto o brindado los medios que hubieran evitado que ellos se produjeran, siempre que la disposición de dichos medios sea exigible atendiendo a la naturaleza del servicio que ofrece."

De acuerdo con lo anterior, los establecimientos de Salud son responsables solidarios junto con los profesionales que hayan cometido acciones negligentes en contra de los pacientes. Sin embargo, se omiten a los internos de medicina de toda responsabilidad en el caso que estos realizaran alguna acción -producto de su impericia- que provoque daños a los pacientes. Si bien es cierto, los internos al no ser trabajadores de los Hospitales -debido a que son practicantes pre profesionales- no 
tienen una relación laboral con estos, acaso ¿no deberían hacerse responsables de sus actos?

En mi opinión, si tienen responsabilidad. Existe una relación extracontractual entre el paciente y el interno, por lo que debe existir una indemnización por parte de este último hacia el primero. No obstante, no existe norma alguna que diga expresamente lo mencionado, poniendo así este tema en el limbo.

Por último, así como el objetivo principal de esta tesis es sentar las bases para una mejor protección de los derechos de los internos, también lo es para señalar que responsabilidades deberían tener; entonces, es imperativo que se tome en cuenta sobre la indemnización y la responsabilidad extracontractual que recae sobre los internos de medicina, con lo que de esa manera se podrá establecer un mejor sistema de responsabilidades y sanciones, garantizando así la seguridad de los pacientes que son atendidos por los internos de medicina.

\section{Conclusiones:}

Conforme con lo descrito, se puede concluir que, todas las normas mencionadas en efecto están orientadas a proteger los derechos de los internos de medicina; lamentablemente, no se encuentran bien planteadas. Es entonces que, se debe plantear una sola norma que 
contenga todo lo necesario para velar por los derechos de los internos de medicina e imponerles responsabilidades.

\subsection{Marco Legal Internacional:}

A manera de contraste, utilizare como ejemplo el marco legal internacional de tres países de Sudamérica, y de esa forma comparar la legislación peruana con la internacional en relación a los derechos otorgados a los internos de medicina.

A continuación, describiré la normativa de Colombia, Argentina

y Chile en torno al tema de mi investigación, para que de esa manera se pueda evidenciar cuanto retraso existe en este ámbito y la poca o nula preocupación de nuestros legisladores

\subsubsection{LEGISLACIÓN COLOMBIANA: INTERNADO DE MEDICINA EN}

\section{LA CIUDAD DE BOGOTÁ}

En la legislación colombiana, los practicantes pre profesionales están regidos por la Ley 789, que fue publicada el 27 de diciembre de 2002, en su artículo $31^{\circ}$ se menciona lo siguiente:

“a) Las prácticas con estudiantes universitarios, técnicos o tecnólogos que las empresas establezcan directamente o con 
instituciones de educación aprobadas por el Estado, de conformidad con las Leyes 30 de 1992 y 115 de 1994 o normas que la adicionen, modifiquen o sustituyan, que establezcan dentro de su programa curricular este tipo de prácticas para afianzar los conocimientos teóricos. En estos casos no habrá lugar a brindar formación académica, circunscribiéndose la relación al otorgamiento de experiencia y formación práctica empresarial. El número de prácticas con estudiantes universitarios debe tratarse de personal adicional comprobable con respecto al número de empleados registrados en el último mes del año anterior en las Cajas de Compensación (...)”

Por otro lado, a diferencia de los practicantes en Perú, los practicantes pre profesionales en Colombia no reciben remuneración alguna por las labores realizadas en sus centros de aprendizaje. Esto, a pesar de los proyectos de ley presentados en aras de procurar una subvención para este sector; sin embargo, la respuesta del gobierno colombiano siempre ha sido negativa, escudándose en los altos costos que tendrían que afrontar las empresas al otorgar un beneficio monetario a los estudiantes. 
Con respecto a los internos de medicina, en la legislación colombiana existe el Decreto número 2376 de 2010 del Ministerio de la Protección Social, este regula el número de horas máximas que un interno debe de cumplir diaria y semanalmente, un seguro de salud en caso de accidentes, así como un seguro con una póliza de responsabilidad civil extracontractual que cubre riesgos frente a terceros, además de riesgos biológicos. y autoevaluaciones que los centros hospitalarios deberán cumplir ante la Comisión intersectorial de talento humano en salud.

El primer punto a resaltar en dicha legislación, es el horario en el cual los internos desarrollaran sus prácticas, estipulado en el artículo 15, literal c) del Decreto número 2376 de 2010, que dice lo siguiente:

c) Los turnos de las prácticas formativas de los estudiantes se fijarán atendiendo las normas, principios y estándares de calidad en la prestación del servicio de salud y de bienestar de los estudiantes y docentes. En cualquier caso, los turnos serán de máximo 12 horas, con descansos que garanticen al estudiante su recuperación física y mental y no podrán superar 66 horas por semana" 
Como se puede apreciar, los turnos que realizaran los estudiantes de medicina son de 12 horas como máximo diariamente; teniendo como opción poder escoger entre tres turnos, el turno mañana (de 7am a 7pm), el turno noche (de 7pm a 7am) y el turno libre (el interno escoge las horas en las que asistirá al centro hospitalario).

Sin duda, 12 horas diarias de trabajo son excesivas, aunque estas se verían compensadas con las 24 horas que son brindadas a todos los internos que hayan cumplido con el turno de guardia hospitalaria. Además, se les otorgara otro descanso de tres horas cuando los practicantes tengan que retomar sus labores al finalizar el turno de guardia nocturna.

Entonces, con una mejor distribución de horario por parte de los centros hospitalarios y con un número mayor de horas de descanso después de cada turno de guardia hospitalaria se tendrá como resultado a internos de medicina con mayor capacidad de rendimiento en las prácticas, se evitarán accidentes tanto biológicos como humanos y habrá una mejor retroalimentación de las enseñanzas impartidas por parte del residente a los internos. 
El segundo punto que llama la atención de la norma, es el establecido en el literal a) del artículo 15, que menciona la lo siguiente:

“a) Los estudiantes que realicen prácticas formativas que impliquen riesgos frente a terceros o para su salud, estarán cubiertos por pólizas de responsabilidad civil extracontractual y de riesgos biológicos, con una cobertura no inferior a 250 salarios mínimos legales mensuales vigentes para cada una. “

Este literal es de suma importancia, puesto que regula la responsabilidad civil extracontractual que tiene el interno de medicina frente a terceros (pacientes) por causarles cualquier tipo de daño en el ejercicio de sus prácticas pre profesionales. En comparación con otras legislaciones, la normativa colombiana sienta un precedente; ya que, procura la existencia de un fondo que tendrá que ser financiado por las instituciones que forman parte de la relación docencia- servicio (hospitales y universidades) y de esa manera poder cubrir los gastos que dichas impericias generen.

Como se sabe, no existe una relación laboral entre el hospital y el interno -un contrato de por medio-, mucho menos hay una relación contractual entre el paciente y el interno, de ahí que la responsabilidad civil devenga en extracontractual. Asimismo, es la primera en desligar 
del círculo de responsabilidad al médico residente, que al ser el supervisor de la labor de los practicantes era quien respondía por todas las impericias cometidas por parte del interno debido a su poca experiencia.

De igual manera, el hospital también asume los gastos en caso el interno de medicina sufra algún accidente debido al riesgo biológico que implica trabajar en un centro hospitalario. Es decir, la norma reconoce que los internos tienen responsabilidad por las faltas que comenten frente a terceros, pero que no tienen culpa, por ello la póliza que cubre estos casos.

Otro punto que vale la pena resaltar, es el de las autoevaluaciones de los hospitales escuela, este se encuentra establecido en el artículo 20, que dicta lo siguiente:

"Para que las instituciones interesadas sean reconocidas como escenarios de práctica, deberán realizar una autoevaluación que les permita determinar el cumplimiento de las condiciones necesarias para el desarrollo adecuado de las prácticas formativas en el programa o programas que considere pertinente. Así mismo, la autoevaluación le permitirá a la institución establecer el número de cupos que puede ofrecer por programa, de acuerdo con su capacidad operativa, 
administrativa y técnico científico.

Entre los criterios a tener en cuenta se deben considerar al menos los siguientes:

a. Existencia de una estructura orgánica y funcional que incluya $e$ integre las prácticas formativas en la misión de la institución

b. Existencia de procesos formales

relacionados con el desarrollo de las prácticas formativas en la institución

c. Recurso humano idóneo vinculado formalmente a la gestión de las prácticas formativas

d. Infraestructura física y técnico-científica adecuada para el desarrollo de las prácticas formativas

e. Actividad operacional que la institución lleva a cabo, relacionada con el volumen de usuarios, pacientes, servicios o actividades, que sustentan la formación teórico-práctica de los estudiantes en cada programa, según el nivel de 


\section{preparación y de complejidad institucional”}

Esta norma estipula que los centros hospitalarios que ostenten ser reconocidos como hospitales universitarios deberán contar con diversos requisitos, entre los cuales se encuentran: tener la infraestructura necesaria para poder albergar a los internos de medicina que realicen prácticas en sus instalaciones, personal que esté capacitado y además que pueda impartir sus conocimientos a los practicantes.

En mi opinión, este artículo en particular fomenta que los hospitales se preocupen por tener y ofrecer las mejores condiciones tanto educativas como sanitarias. Además, en el artículo 23 se habla de las inspecciones a realizarse en los centros hospitalarios con el fin de corroborar el correcto cumplimiento de la norma, pero sobre todo para informar a la Comisión Intersectorial del Talento Humano en Salud de ello, y es que, si no se cumple con la norma, los centros hospitalarios pierden el título de hospitales universitarios.

Conforme a ello, en el artículo 24 se otorgan siete años como período máximo del reconocimiento de hospital universitario, luego de ello el hospital entrará en evaluación nuevamente para revalidar el título. Esta normativa tan estricta hace posible que los internos de 
medicina tengan las mejores condiciones para aprender y realizar sus prácticas pero que sobretodo lo hagan en centros que se preocupen por ello.

En conclusión, la normativa colombiana si bien es cierto no brinda una subvención económica a los practicantes de medicina, por lo menos tiene cubiertas todas las necesidades restantes en su ámbito laboral, lo que hace tomarla como ejemplo.

\subsubsection{LEGISLACIÓN ARGENTINA: INTERNADO DE MEDICINA} EN LA CIUDAD DE BUENOS AIRES.

En la legislación argentina, a las prácticas pre profesionales se les denomina pasantía educativa, la cual se encuentra regulada por la (Ley 26.427, 2008, Art. 2), promulgada el 18 de diciembre de 2008, y se define de la siguiente manera:

"Artículo $2^{\circ}$ "conjunto de actividades formativas que realicen los estudiantes en empresas y organismos públicos o empresas privadas con personería jurídica, sustantivamente relacionada con la propuesta curricular de los estudios cursados en unidades 
educativas, que se reconoce como experiencia de alto valor pedagógico, sin carácter obligatorio"

Esta Ley, reglamentada en 2009, plantea distintos puntos encontrándose entre los más importantes, los siguientes; un máximo de 20 horas laborables por semana, régimen de asistencia y licencias para los pasantes por exámenes, enfermedades o accidentes, cobertura médica de emergencias a cargo de la empresa u organización o entidad y Planes de capacitación tutorial que resulten necesarios. Además, los pasantes recibirán una suma de dinero de carácter no remunerativo en calidad de asignación (estímulo), que se calculará sobre el salario básico del convenio colectivo aplicable a la empresa y, que será proporcional a la carga horaria de la pasantía.

Por otro lado, la normativa que regula la función que desempeñan los practicantes pre profesionales en salud data de 1967 en donde se promulgo la (Ley 17.132, 1967, Art. 41), sobre el ejercicio de la medicina, odontología y actividades auxiliares. En ella, se especifica quienes son considerados como practicantes de medicina.

Artículo $41^{\circ}$ "Se consideran practicantes los estudiantes de medicina u odontología que habiendo aprobado las materias básicas de sus respectivas carreras realicen actividades de aprendizaje en instituciones 
asistenciales, oficiales o privadas. Su actividad debe limitarse al aprendizaje y en ningún caso pueden realizar funciones de las denominadas por esta ley de colaboración. Los practicantes de medicina $u$ odontología sólo podrán actuar bajo la dirección, control personal directo y responsabilizado de los profesionales designados para su enseñanza y dentro de los límites autorizados en el párrafo anterior."

En dicho país, se le denomina Internado Anual Rotatorio (IAR) al internado de medicina. Al igual que en la normativa peruana, durante el periodo que dure el programa de internado, el interno tendrá que pasar por distintas especialidades de la medicina para que de esa forma tenga un mejor y mayor aprendizaje de la carrera.

Para poder acceder al régimen de internado anual rotatorio, se debe de haber culminado con los seis (6) años de la carrera y haber aprobado las materias correspondientes - requisitos comunes pedidos en cualquier facultad de medicina-

Ahora bien, el desarrollo del IAR depende de cada facultad de medicina o de los hospitales en los que se quiera llevar a cabo este; sin embargo, existen características comunes a todas las facultades, entre 
las cuales se encuentran las siguientes: el programa al 100\% dura alrededor de 32 semanas o 8 meses divididos en rotaciones que serán escogidas por los internos de acuerdo al hospital seleccionado; el internado es obligatorio y no se otorga ninguna subvención económica; se puede escoger en que Hospital realizar cada una de las rotaciones y en qué periodo del año lectivo llevarlas - de acuerdo al cronograma de inscripción-; el número de días otorgados para faltas varía entre los 6 y 7 por cada mes; y el horario de labores diarios no sobrepasa las seis horas.

A simple vista, el IAR brinda muchas más ventajas que cualquier otro programa de internado. Sin embargo, por su naturaleza flexible lamentablemente crea muchas confusiones; al no tener una estructura definida y regirse conforme a las "necesidades" de los alumnos, no se cuenta con un número fijo de internos en cada rotación y mucho menos en cada hospital. Además, al ser reducidas las horas diarias de labores, el nivel de aprendizaje decrece y al no durar un año como su mismo nombre refiere, se acortan también los tiempos de cada rotación. Teniendo como resultado, a mi parecer, una deficiente enseñanza de la parte práctica de la carrera de medicina.

En conclusión, existen aspectos del programa argentino que vale la pena resaltar, como la flexibilidad en la selección de hospitales que permite llevar a cabo las rotaciones en instituciones que se especialicen 
en cada de las ramas de la medicina y la facilidad que se brinda a los estudiantes de faltar cierto número de días, sin perder la oportunidad de continuar siendo parte del internado. Pero aparte de ello, en mi opinión, el IAR deja mucho que desear.

\subsubsection{LEGISLACIÓN CHILENA： INTERNADO DE MEDICINA EN LA CIUDAD DE SANTIAGO.}

Al igual que en la normativa peruana, los practicantes pre profesionales y profesionales en Chile no se encuentran sujetos a un contrato laboral per se; sino que, cuentan con un convenio gracias al cual pueden realizar un periodo de prácticas en una empresa o institución, la cual según el Artículo $\mathrm{N}^{\circ} 8$ del Código del Trabajo. debe proporcionar al alumno en práctica el beneficio de la colación y movilización o pagar una asignación compensatoria por tales beneficios.

“Art. $8^{\circ}$. (...) Tampoco dan origen a dicho contrato los servicios que preste un alumno o egresado de una institución de educación superior o de la enseñanza media técnico-profesional, durante un tiempo determinado, a fin de dar cumplimiento al requisito de práctica profesional. No obstante, la empresa en que realice dicha práctica le proporcionará colación y 
movilización, o una asignación compensatoria de dichos beneficios, convenida anticipada $y$ expresamente, lo que no constituirá remuneración para efecto legal alguno" (la negrita es nuestra)

En el caso de los internos de medicina, estos al ser practicantes pre profesionales también deberían de gozar de los mencionados beneficios; sin embargo, de la revisión de los diferentes reglamentos de medicina de las distintas universidades chilenas, pude llegar a la conclusión de que básicamente los futuros internos de medicina -para obtener dicha calidad- deben de presentar todos los documentos necesarios que permitan a los hospitales desligarse de cualquier responsabilidad frente a una eventualidad; específicamente, me refiero a que los internos deben de presentar además de un seguro académico, un seguro complementario que cubra cualquier tipo de accidente, el cual al ser el Hospital Docente el ente "formador" es quien debería proporcionarlo.

Con respecto a la forma en la que se desarrolla el programa de internado en el país chileno, se pueden resaltar los siguientes puntos; por ejemplo, la jornada diaria de labores consta de un periodo de doce (12) horas, al día son asignados dos internos por cama y por cada unidad de atención, y se designara un supervisor por cada ocho (8) estudiantes. Por otro lado, existen ciertas restricciones a las que se encuentran 
sujetos, como no poder retirar los exámenes médicos realizados a los pacientes que atienden, no poder llenar historias clínicas, y mucho menos solicitar interconsultas.

Ahora bien, con respecto a la normativa estipulada en el artículo $\mathrm{N}^{\circ} 8$ del Código del Trabajo, esta no se cumple; ya que, los internos medicina tienen que costear los gastos de movilidad, alimentación (colación) y demás que originen de dicho programa, situación que no es la más adecuada para los internos que aún siguen costeando las mensualidades (arancel) cobradas por sus respectivas universidades.

De lo descrito anteriormente, se evidencia que no existe mucha información con la que se pueda realizar un análisis más exhaustivo de la situación del programa de internado médico en Chile, ya sea por el mismo desinterés del Estado en regular de manera específica sobre el tema de modalidades formativas o porque como en el caso peruano, la normativa existente es supuestamente la suficiente.

No obstante, se puede concluir que dicho programa se encuentra en su mayoría orientado a asegurar no al lado más débil de la relación, sino al que ya cuenta con mayores privilegios, estos son los Hospitales. Lamentablemente, al igual que en las legislaciones de los demás países descritos en la presente investigación, aún hay mucho por trabajar para mejorar la situación de los internos y de todo el programa. 


\section{CAPITULO III}

\section{Problemática de los Internos de Medicina}

Como señalé en capítulos anteriores, la labor que ejerce un practicante pre profesional de medicina es sumamente riesgosa, ardua y llena de complicaciones. Todo ello, no solo afecta su desarrollo académico sino también su salud física y mental. A continuación, expondré cuales son las principales quejas que tienen los internos, en qué estado desarrollan sus prácticas y lo que conlleva no tener un adecuado régimen que regule el mencionado programa. Sustentándome en entrevistas realizadas en distintos Hospitales escuela en los que se desarrollan los programas de internado de medicina. 


\subsection{Principales problemas del Programa de Internado $\underline{\text { Médico }}$}

Durante el año 2015, desarrolle un cuestionario de preguntas acerca del programa de internado de medicina que fueron la base para las entrevistas que realice a un número de internos de medicina de 12 hospitales escuela (5 del Ministerio de Salud, 5 de EsSalud y 2 de Sanidades); algunas de estas entrevistas fueron realizadas presencialmente, y otras a través de internet o por teléfono. Todo lo que describiré se encuentra sustentado en experiencias/vivencias de internos de medicina y además de información recopilada de artículos de revistas que tratan el tema. El primero de los problemas que deben de afrontar es el de la sobredemanda del campo médico.

\subsubsection{Sobredemanda del campo médico}

De acuerdo con un reporte solicitado a la Dirección General de Recursos Humanos del Ministerio de Salud (MINSA-DGGDRH, 2015) -a través de una solicitud de acceso a la información realizada mediante su portal Institucional- solo en sus últimos tres años; el número de internos de medicina sobrepasaba los 3,000 a razón de solo 16 Hospitales Escuela en ESSALUD, 16 Hospitales Escuela del Ministerio de Salud y 3 de sanidades en Lima. Todo ello, repercute en la cantidad de internos de medicina que se encuentra en cada Hospital Escuela 
realizado sus prácticas pre profesionales. Por lo que, es evidente una sobredemanda del campo clínico.

Según (Montenegro Idrogo, Montañez Valverde, \& Sanchez Tonohueye, 2012), se calculó la capacidad de camas disponibles (Como el producto ajustado del "número de camas/estudiantes" por el "total de estudiantes"); para determinar la demanda de estudiantes de medicina según el número de camas requeridas por estudiante teniendo como resultado que existe una sobredemanda del $110 \%$ de alumnos a nivel nacional. Asimismo, como lo señala (Arroyo, 2007), si tomamos en cuenta que durante los últimos años se ha incrementado el número de vacantes para estudiar medicina, en especial en universidades particulares, veremos con mayor preocupación la sobresaturación actual y futura de estos alumnos, en las prácticas clínicas o el internado.

Como se puede colegir del párrafo anterior, debido al excesivo número de internos, no se puede asignar suficientes camas (pacientes) para que los alumnos puedan realizar sus prácticas en cada campo clínico. Generando así que no exista un efectivo desarrollo de los conocimientos adquiridos y teniendo como resultado un bajo aprendizaje practico. 
En conclusión, la única manera de garantizar un efectivo aprendizaje de los internos de medicina es regular el número de vacantes que ofrecen las universidades tanto para la carrera de medicina como para cuando se adjudican plazas para el programa de internado en los distintos hospitales escuela. Asimismo, otra alternativa que lamentablemente es poco viable por lo menos a corto plazo es la de crear nuevos campos clínicos para que así no se saturen los existentes.

\subsubsection{Horario Excesivo de Trabajo}

La jornada diaria máxima de los practicantes pre profesionales es de 6 horas y 30 horas semanales; sin embargo, en el caso de los internos de medicina la jornada de labores de acuerdo con el Decreto Supremo 003-2008-TR, es de 6 horas diarias y 36 semanales incluyendo las guardias nocturnas. Asimismo, se les debe permitir un descanso de 5 horas antes de cada guardia. Lo que significaría que los internos laboran 6 días a la semana a razón de 6 horas diarias, 36 semanales y en total 150 mensuales.

Por el contrario, la realidad es otra. Según las entrevistas realizadas, un interno de medicina se encuentra laborando como mínimo 12 horas diarias 6 días a la semana, el 7mo día por ser domingo solo trabajarían 6 horas. 


\section{Tabla 3.1}

Horas Diarias Laboradas

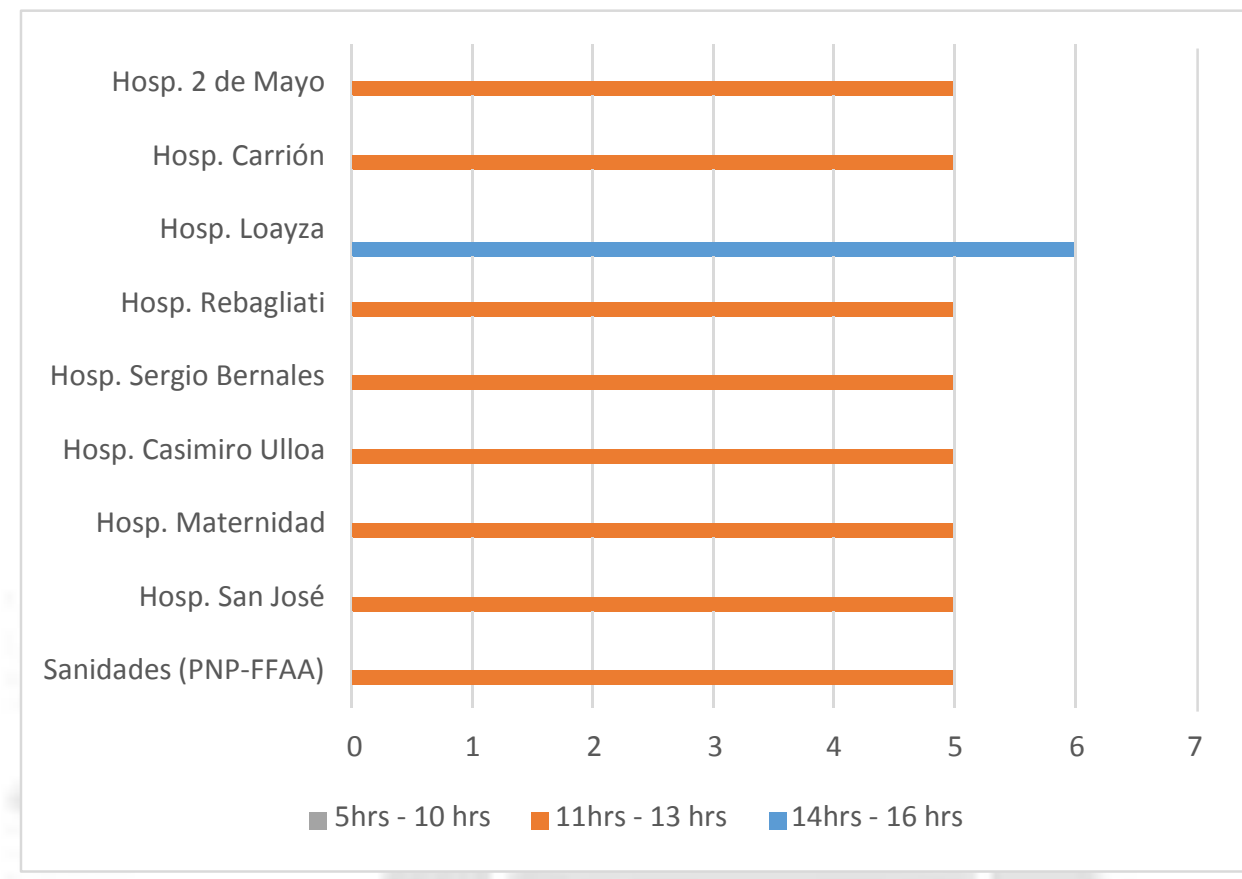

Información extraída de entrevistas realizadas a internos de medicina de 10 hospitales escuela (5 Hospitales del Ministerio de Salud, 5 Hospitales de EsSalud y 2 de sanidades) sobre el número de horas laboradas diariamente. Nota: Hospital Loayza (2014-2015)

Como se puede apreciar, de la totalidad de los hospitales escuela del cuadro, 11 de ellos mantienen a los internos un promedio de 12 horas diarias en sus instalaciones realizando prácticas, mientras que 1 de ellos -Hospital Loayza- lo hace por un promedio de 14 horas diarias; dando como total, unas 78 horas laboradas semanalmente y 390 horas laboradas mensualmente, todo esto sin contar con las guardias nocturnas a las que son asignadas cada 4 días, mismas que tienen que cumplir obligatoriamente sin descanso previo o posterior. 
(Extracto de entrevistas) "El horario de entrada es a las 6 am y de salida a las 7 pm, pero si fui asignada a guardia, normalmente empieza una hora después o inmediatamente; así que, me tengo que quedar hasta el día siguiente que termina a las 6 am y empezar otra vez con el horario normal de internado, ósea trabajo 36 horas seguidas prácticamente sin descanso)

Del extracto de la entrevista, podemos concluir que tampoco se cumple con la disposición contenida en el artículo $\mathrm{N}^{\circ} 3$ del Decreto supremo, que dicta que se les debe otorgar un descanso previo y posterior a cada guardia; de no menos de 5 horas a los internos de medicina. Si bien es cierto, solo incluyo una parte de una sola entrevista, esta es una situación que se refleja en cada uno de los hospitales escuela en Lima.

En suma, los internos de medicina además de estar sometidos a una gran presión por atender de manera adecuada a los pacientes, lo hacen con un alto grado de cansancio debido a las excesivas horas en las que laboran incluidos los días que tienen guardia en los que no descansan por 36 horas seguidas y que se repiten cada 4 días. Esto conlleva a que brinden una atención deficiente y que los expone a diversos riesgos no solo contra su salud sino en contra de la salud de los pacientes.

\section{Consecuencias Jurídicas:}


Ahora bien, de lo descrito anteriormente se evidencia un claro incumplimiento a la norma que, de acuerdo con el artículo $51^{\circ}$ de la Ley 28518 configura la desnaturalización del convenio de modalidades formativas, en los siguientes casos:

"Artículo 51.- Desnaturalización de las modalidades formativas

Se desnaturalizan las modalidades formativas y se entiende que existe una relación laboral común en los siguientes casos:

1. La inexistencia del convenio de modalidad formativa debidamente suscrito.

2. La falta de capacitación en la ocupación específica y/o el desarrollo de actividades del beneficiario ajenas a la de los estudios técnicos o profesionales establecidos en el convenio.

3. La continuación de la modalidad formativa después de la fecha de vencimiento estipulado en el respectivo convenio o de su prórroga o si excede el plazo máximo establecido por la Ley.

4. Incluir como beneficiario de alguna de las modalidades formativas a las personas que tengan relación laboral con la empresa contratante, en forma directa o a través de cualquier forma de 
intermediación laboral, salvo que se incorpore a una actividad

diferente.

5. La presentación de documentación falsa ante la Autoridad Administrativa de Trabajo para acogerse al incremento porcentual adicional, a que se refieren los artículos 17 y 32 o para acogerse a otro tipo de beneficios que la Ley o su Reglamento estipule.

6. La existencia de simulación o fraude a la Ley que determine la desnaturalización de la modalidad formativa.

7. El exceso en los porcentajes limitativos correspondientes" (la negrita es nuestra)

Como se puede apreciar, de los casos resaltados, existe la desnaturalización del convenio de prácticas si es que no se brinda capacitación en la ocupación específica y si no existe la suscripción de un convenio de prácticas pre profesionales; asimismo, el numeral $6^{\circ}$ del mencionado artículo indica la existencia de simulación o fraude a la Ley cuando se configure el incumplimiento de la presente norma. 
En concordancia con el artículo $51^{\circ}$ de la "Ley de Modalidades formativas" se encuentra el artículo $1^{\circ}$ del D.S 003-2008-TR “Dictan medidas sobre jornadas máximas de modalidades formativas reguladas por la Ley $\mathrm{N}^{\circ} 28518$ así como de las prácticas pre profesionales de derecho y de internado de la Ciencias de la Salud", el cual señala que en el caso de sobrepasar el número de horas de la jornada diaria de prácticas, se constituye un supuesto de fraude tipificado en el numeral $6^{\circ}$ del artículo $51^{\circ}$ de la Ley de Modalidades Formativas.

Entonces, de darse cualquiera de los supuestos anteriormente descritos y como lo señala (Gonzales Ramírez \& De Lama Laura, 2010) se generaría la desnaturalización del convenio de prácticas y se entenderá que la vinculación es de naturaleza laboral y de tiempo indefinido. En tenor a ello, describiré en que situaciones se desnaturaliza el convenio a los que están sujetos los internos de medicina.

De acuerdo al numeral $2^{\circ}$ del artículo $51^{\circ}$ de la Ley 28518 , la falta de capacitación en la ocupación especifica y/o desarrollo de actividades distintas a los estudios superiores constituye un supuesto de desnaturalización. En otras palabras, (Gonzales Ramírez \& De Lama 
Laura, 2010) indican que la falta de correspondencia entre lo que el beneficiario verdaderamente realiza y las actividades establecidas como capacitación y/o formación profesional a ser desarrolladas estipuladas en el convenio formativo, así como en el plan y/o programa adjunto a dicho documento. Asimismo, cabe señalar que este supuesto de desnaturalización tiene dos variantes.

La primera, la falta de capacitación en ocupación específica. Conforme (Gonzales Ramírez \& De Lama Laura, 2010), debe entenderse por ocupación especifica aquellas actividades de formación previamente definidas que el beneficiario (interno) debe desarrollar para la adquisición del conocimiento o experiencia; en tal sentido, puede decirse que la ocupación especifica es el objeto de la modalidad formativa, sin el cual sería imposible alcanzar la finalidad buscada, ya que, es imposible imaginar alcanzar el conocimiento o aprender la técnica de una actividad sin que ella sea claramente definida.

En resumen, se debe definir cuáles son las actividades específicas que deben de cumplir los internos y para la que deben de recibir una capacitación adecuada que les procure especializarse en dicha función. Sin embargo, como detallé este el capítulo, no existe tal “capacitación” que ayudé a los practicantes a desarrollar las labores asignadas y para las que no se encuentran lo suficientemente 
entrenados; creando así un ambiente de inseguridad para la población que se atienden en los hospitales escuela, y sin que estos últimos tengan repercusión alguna.

La segunda, como establece (Gonzales Ramírez \& De Lama Laura, 2010), el desarrollo de actividades distintas del estudio superior. Este supuesto de desnaturalización se genera cuando el desarrollo de las actividades formativas no se vincula con lo aprendido en el centro de formación superior o universitaria. Para el caso en concreto de los internos de medicina, este supuesto no se aplicaría directamente, pues como es sabido la carrera de medicina es muy amplia por lo que los internos tienen que realizar prácticas en todas las ramas y así adquirir la experiencia necesaria.

Sin embargo, asignarles responsabilidades y deberes propios de un médico residente o contratado, tal vez no sea considerado como supuesto de desnaturalización del convenio de prácticas, pero debería de serlo. Los internos de medicina son tratados como una especie de mano de obra barata a la que no es necesario brindarle ningún tipo de protección y quienes cubren en más de una forma la función de un médico residente, realizando muchas veces el trabajo que este debería hacer. En nuestro país se considera que los internos deben aprender 
sobre la marcha, lo que perpetua la cadena de abusos que se comenten en contra los practicantes.

Por último, el numeral $6^{\circ}$ del Artículo $51^{\circ}$ de la mencionada Ley de Modalidades Formativas, señala que existe simulación o fraude a la Ley que determine la desnaturalización en el caso de que se exceda la jornada formativa. Conforme a con dicho numeral, el Decreto Supremo 003-2008-TR que indica que los practicantes en salud tienen como jornada máxima seis (06) horas diarias.

Igualmente, (Gonzales Ramírez \& De Lama Laura, 2010) mencionan que para que se constituya un supuesto de desnaturalización el exceso de la jornada formativa deberá ser proporcional y razonable. Es decir, aquella situación en la que el beneficiario (interno) de manera reiterada y por amplios márgenes exceda la jornada máxima permitida; en este caso será más evidente y sencilla la determinación de la desnaturalización de la vinculación formativa.

Como hice referencia casi al principio del capítulo, en la mayoría de Hospitales donde realizan prácticas pre profesionales los internos de medicina, estos permanecen como mínimo alrededor de doce (12) horas diarias laborando, en el mejor de los casos. lo que incumple en gran 
medida lo designado por el D.S 003-2008-TR, creando así un supuesto de desnaturalización del convenio de prácticas.

No obstante, en el artículo $4^{\circ}$ del referido Decreto, no se hace alusión a la desnaturalización del convenio de prácticas en el caso que se sobrepase el número de horas de la jornada diaria de los practicantes de medicina. Sin embargo, en el caso del horario de prácticas de los estudiantes de derecho, que este decreto también señala, si se hace referencia sobre el supuesto de desnaturalización.

Si bien es cierto, estas carreras profesionales son muy distintas, de todas maneras, dicho supuesto debería estar recogido para ambos. Empero, al no cumplirse la jornada diaria de labores para los internos medicina, se estaría incurriendo en el supuesto de desnaturalización del convenio de prácticas.

Entonces, más del $90 \%$ de internos de medicina pasarían a ser trabajadores regulares de los hospitales con todos los beneficios correspondientes. A pesar de ello, no es una situación que se dé, por el hecho de que los practicantes en salud no reportan estas ya conocidas condiciones por las que pasan diariamente, y tampoco el Ministerio de 
Trabajo - encargado de la fiscalización- tiene interés de que la realidad de los internos cambie.

\subsubsection{Sobrecarga Laboral}

Por otro lado, aparte del cansancio que enfrentan diariamente se suma la sobrecarga laboral que se traduce en el número de pacientes que atienden por día o también las llamadas camas asignadas. Como mencione al principio de esta tesis, el programa de internado médico se divide en 4 módulos o rotaciones que vienen a ser una especie de cursos en 4 materias distintas, en cada una de ellas se le asigna al interno la atención de pacientes internados, la redacción de historias con detalle de la patología y su respectiva guardia nocturna.

De acuerdo a los resultados de las encuestas, cada interno atiende alrededor de 8 camas como mínimo y de 15 camas como máximo, además de realizar las órdenes para los análisis, o practicarlos ellos mismos; asimismo, se encuentran a la disposición entera de los médicos tratantes para asistirlos en las cirugías programadas del día, redactan las historias clínicas, realizan el papeleo de alta médica, y efectuar un adecuado diagnostico a los pacientes. 
Todo lo descrito sin lugar a dudas lleva una carga laboral demasiado alta para los internos, que se incrementaría en dos de las cuatro rotaciones. El 100\% de los entrevistados refieren que la rotación de Gineco-obstetricia y medicina general, son excesivamente más demandantes, debido a que en la primera atienden una cantidad de partos diarios que supera la atención máxima de 15 camas diarias, sobre todo si realizan la rotación en el Hospital de la Maternidad de Lima, y en la segunda, al no tratarse de una área específica de la medicina, existen pacientes con distintas patologías que deben ser examinadas con detenimiento para poder ser diagnosticadas con exactitud, haciendo que el interno de medicina tome más tiempo del debido en detectarlas.

Pero eso no es todo, los internos están sometidos a un intenso estrés generado por la sobrecarga laboral que es consecuencia directa de la gran suma de pacientes que tiene cada hospital. Asimismo, como consecuencia de ese estrés, los médicos contratados y tratantes tienen un trato poco amable con los practicantes de medicina, llegando en muchos casos a maltratarlos verbal y físicamente.

Además de sumarle el maltrato que reciben en muchos casos de parte de los familiares de los pacientes, los internos estaría más que predispuestos a sufrir severas enfermedades mentales tales como la depresión y, en realidad la mayoría la sufre. En efecto, un gran número 
de los internos entrevistados hace referencia a que sufrió de depresión durante el programa de internado médico.

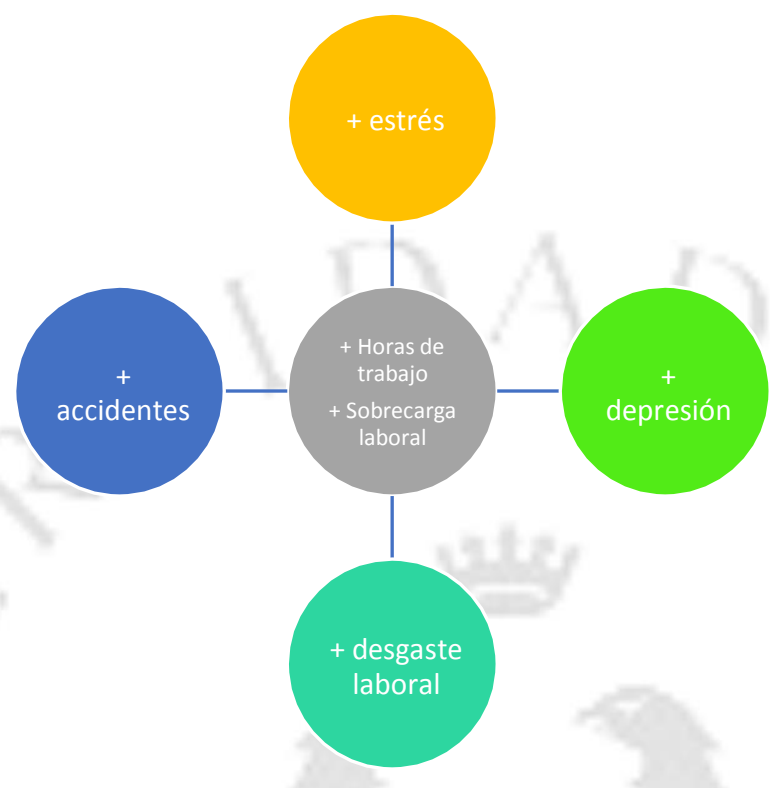

Es que, en efecto, la sobrecarga laboral aparte de causar depresión en los internos, además hace que estos no atiendan de manera eficiente y adecuada a los pacientes, produciendo así una obstrucción en la relación médico-paciente que de todas maneras va a dificultar un diagnostico óptimo. Aunque tampoco se debe olvidar que el número de accidentes laborales se incrementaría debido a esto.

En conclusión, un horario excesivo de labores sumado a la sobrecarga laboral del programa de internado desgasta de sobremanera a los internos de medicina, teniendo como consecuencia un trato distante con los pacientes y el incremento de los accidentes laborales. 
Lamentablemente, esta situación no tiene cuando acabar, a menos que el Estado tome cartas en el asunto y regule de mejor manera las funciones, deberes y derechos de los practicantes de medicina.

\section{Tabla 3.2}

Problemas derivados del sobretiempo laboral de los internos de medicina

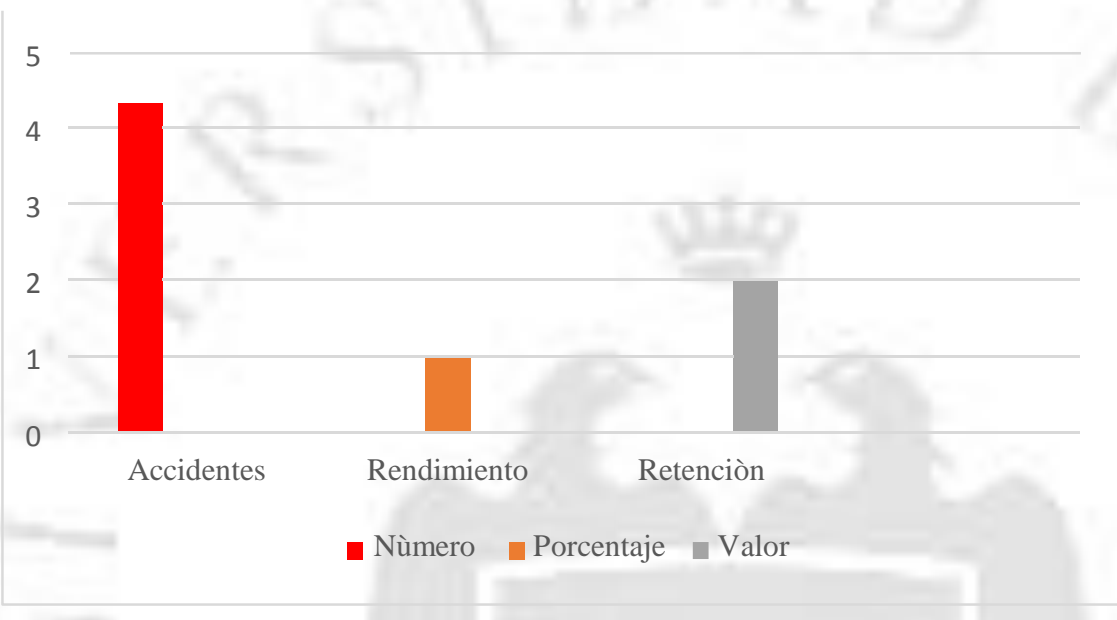

Cuadro sobre los Problemas derivados del sobretiempo laboral de los internos de medicina: información recabada de entrevistas realizadas a diversos internos de medicina. 2015.

\subsubsection{Inexistencia de ambientes de descanso}

Conforme lo exige el programa de internado médico, las guardias nocturnas son obligatorias para todos los internos de medicina. Estas, tiene una duración promedio de 12 horas, empezando desde las $8 \mathrm{pm}$ y terminando a las 6am del día siguiente. Aunque, durante todo este lapso de tiempo, los practicantes se encuentran a entera disposición de cualquier emergencia, no son permanentemente llamados; por lo que, normalmente deberían de estar descansando en ambientes destinados para pernoctar. Ya que, vienen de estar trabajando más de 12 horas. 
Sin embargo, esto es casi imposible. En la mitad de los Hospitales, en los que desempeñaron funciones los internos de medicina, no se cuenta con un ambiente únicamente de descanso con frazadas y camas suficientes para todos los internos que realizan guardias. Y en la otra mitad de Hospitales que, si contaban con camas, estas se hallaban en deplorables condiciones (sábanas manchadas y solo colchones en mal estado)

Un caso extremo, es por lo que tienen que pasar los internos que laboran en las instalaciones del Hospital Sergio Bernales. En dicho Hospital escuela el ambiente destinado a contar con camas para el descanso de los internos se encuentra clausurado desde el 2014 por constantes quejas, en su mayoría de robos y por qué se han encontrado a trabajadores manteniendo relaciones sexuales. Por ello, la directiva del Hospital decidió que no se contaría más con una zona de camas para el descanso (información extraída de entrevistas realizadas a internos de medicina del Hospital Sergio Bernales)

Esto afecta de sobremanera a los internos de medicina que después de trabajar bajo altos grados de estrés necesitan descansar, y que lo tienen que hacer ahora durmiendo en sillas, en detrimento de su desempeño a la hora de atender a los pacientes e incrementando el riesgo de accidentes laborales debido a su falta de descanso. 
Tabla 3.3

Camas disponibles para el descanso

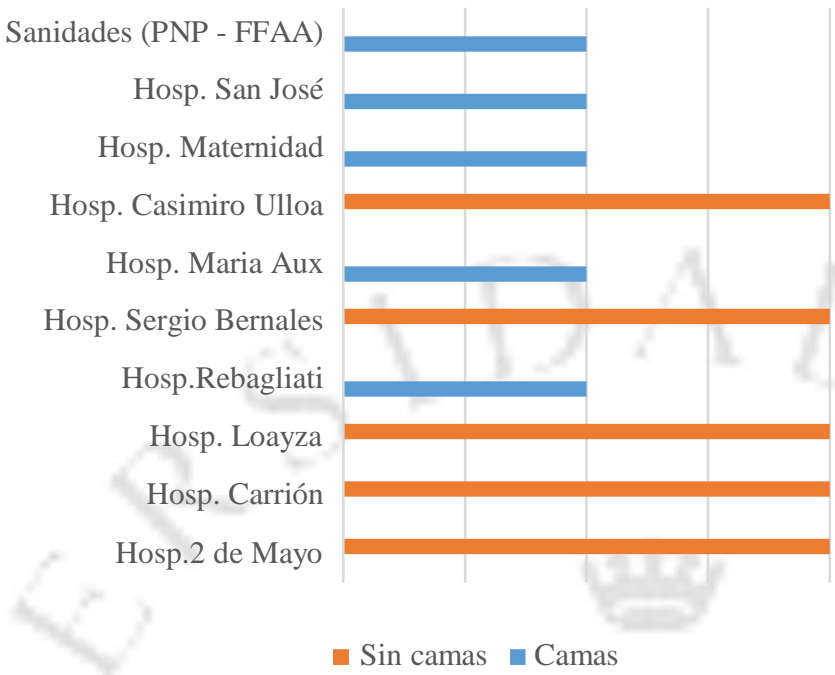

Información extraída de entrevistas realizadas a internos de medicina de 10 hospitales escuela (5 Hospitales del Ministerio de Salud, 5 Hospitales de EsSalud y 2 de sanidades) sobre si contaban con camas para su descanso en el horario de guardias

Asimismo, de las entrevistas realizadas también se pudo recoger la información de que en los Hospitales donde sí se contaban con camas, estas no contaban con sábanas y o frazadas con las que los internos pudieran cubrirse mientras pernoctaban, o en caso contrario las sábanas que había se encontraban manchadas con fluidos no identificados, haciendo que sean prácticamente inutilizables. Por lo que, en un gran número de ocasiones los propios internos debían llevar sus propias sábanas y frazadas, para aguantar las bajas temperaturas de las madrugadas. 
En conclusión, la falta de lugares para el descanso además de camas y frazadas es un problema que no se debe a tomar a la ligera porque afecta severamente el desempeño laboral de los internos de medicina que de todas maneras se traduciría en una atención deficiente a los pacientes y lo que es más peligroso aún en el crecimiento del número de accidentes laborales, así como en la alta posibilidad de que por culpa de la privación de sueño los internos puedan herir a los pacientes a la hora de realizar la toma de muestras de sangre o cuando efectúan las curaciones necesarias.

\subsubsection{Accidentes Laborales}

Una de las más serias amenazas que enfrentan los estudiantes de medicina durante su práctica clínica, de acuerdo a lo señalado (Inga, Lopez, \& Kamiya Carlos, 2010) por es la posibilidad de exposición a accidentes biológicos, debido en la mayoría de los casos a la inexperiencia y el escaso desarrollo de las habilidades manuales. Como parte de sus labores diarias para adquirir experiencia en el campo médico, los internos de medicina deben de tomar muestras de sangre, fluidos, realizar curaciones, etc. Por lo que, están en constante contacto con objetos punzo-cortantes, materiales infectados, líquidos y secreciones corporales. Debido a esto, los accidentes biológicos están a la orden del día. 
Como una prueba de ello, se encuentran las entrevistas que realice a los internos de medicina de 12 hospitales distintos. De los entrevistados, el total de ellos aducen haberse cortado por lo menos una vez con instrumentos punzocortantes y pincharse con las jeringas un incontable número de veces. Los casos más extremos son en los que al obtener como muestras fluidos de los pacientes, estos fueron derramados al suelo por los propios internos de manera accidental, provocando que otras personas pertenecientes al staff médico se resbalaran, confusión de tubos con muestras de sangre entre pacientes infectados con VIH y pacientes no infectados, derramamiento de sangre al piso a la hora de tomar muestras, y demás tipos de accidentes.

Asimismo, (Inga, Lopez, \& Kamiya Carlos, 2010) también menciona la existencia de una severa falta de educación y conciencia que se tiene sobre la magnitud del riesgo que implican los accidentes biológicos; así, las precauciones y acciones recomendadas a realizar luego de la exposición, no se ejecutan, por considerar irrelevantes a la mayoría de ellas.

Todo lo mencionado anteriormente tiene como consecuencia, la transmisión de enfermedades tales como Hepatitis B y C, Neumonía, Infecciones del torrente sanguíneo, Infecciones del tracto digestivo, tuberculosis, VIH, etc. -que se encuentran presentes en todos los hospitales del Perú-. Ciertamente, los accidentes no van a dejar de 
existir en un ámbito tan riesgoso como es el sector salud; por ello, lo que se busca es reducir la frecuencia de estos mediante métodos de prevención tales como capacitaciones, materiales de bioseguridad, vacunas y supervisión constante.

\section{$\underline{\text { 3.2 Tipos de enfermedades e infecciones transmisibles en los }}$}

\section{$\underline{\text { Hospitales Escuela }}$}

En el Perú, como lo indica el (Ministerio de Salud, 2014) más de 160 mil trabajadores de salud corren el riesgo de contagiarse de enfermedades como hepatitis B, hepatitis C, VIH-SIDA, debido a las condiciones inseguras en el uso de material punzocortante como agujas, jeringas y bisturís. Pero también, existe el riesgo de contagio a través del contacto con pacientes; en este caso, se trataría de enfermedades respiratorias o infecciones del tracto digestivo.

Asimismo, existe la posibilidad de que los internos contraigan infecciones derivadas de la manipulación de fluidos utilizados como muestras para análisis. De igual forma, si en los hospitales no existe un adecuado protocolo de desecho de materiales biocontaminados; es posible que, los practicantes también puedan adquirir enfermedades a través de esta vía. 


\subsubsection{Métodos de prevención de transmisión de enfermedades}

Los Hospitales son focos infecciosos en los que pululan decenas de enfermedades infectocontagiosas; por ende, los internos de medicina están constantemente en riesgo de adquirir cualquier tipo de enfermedades. Por esta razón, en cada centro hospitalario deben de existir métodos de prevención de transmisión de enfermedades tales como charlas en bioseguridad, capacitaciones en materia de manejo de residuos médicos, entrega de material de bioseguridad, vacunas, seguros de trabajo de riesgo y supervisión constante.

El primero de estos, es el más importante ya que el uso de un adecuado material de bioseguridad -que sirve como barrera inicial- es fundamental para proteger al interno de cualquier contacto con cualquier tipo de fluido o bacterias que pueda poner en riesgo su salud.

\section{A) Material de bioseguridad}

La bioseguridad es un tema generalmente dejado de lado, como menciona él (Ministerio de Salud, 2004) ya sea por desconocimiento, por cuestiones presupuestarias a la hora de tener que invertir en equipamiento de seguridad, por falta de un entrenamiento apropiado del personal técnico, y por sobre todo el "a mí no me va a pasar nada". 
Los equipamientos de seguridad a los que me refiero deben de constar en batas quirúrgicas, guantes, mascarillas, gorras quirúrgicas y protectores para el calzado -todos deben ser desechables- y deben ser repartidos a todo el personal médico de los Hospitales, pero sobre todo a los internos de medicina que por estar recién aprendiendo a desempeñar la labor de médicos son más proclives a cometer accidentes en los que se pueden redamar sustancias o fluidos infectados.

Sin embargo, la realidad es otra. De los internos entrevistados que laboraron en 12 hospitales escuela, se puede extraer que en 10 de ellos no se les entrego ningún material de bioseguridad. Lo que es alarmante; puesto que, el material de protección es la primera barrera que debe obstaculizar el contagio. Asimismo, la mayoría de los entrevistados afirman que ellos mismos deben de comprar el equipo de protección en aras de proteger no solo su salud sino la de los pacientes con los que mantienen permanente contacto. Además, en muchos casos hacen referencia a que inclusive tuvieron que llevar agujas e hilo comprados con sus propios medios para poder realizar curaciones. 
Tabla 3.4

Materiales otorgados por los Hospitales

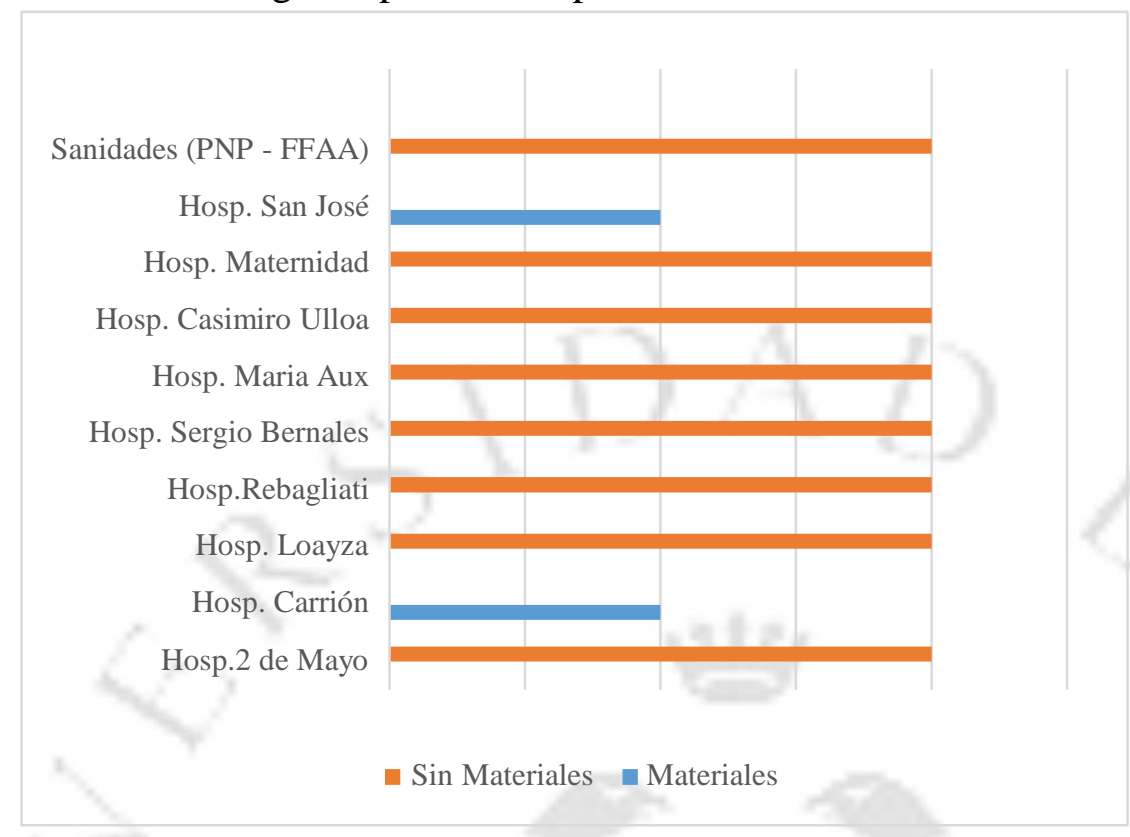

Información extraída de entrevistas realizadas a internos de medicina de 10 hospitales escuela (5 Hospitales del Ministerio de Salud, 5 Hospitales de EsSalud y 2 de sanidades) sobre si se les otorgan materiales médicos (guantes, tapa bocas, mandiles, agujas, batas quirúrgicas, cubre zapatos, etc.).

Por otro lado, en los Hospitales en los que si se les entregaba equipamiento biomédico se hacía de forma racionalizada. Por lo que, muchas veces se utilizaban las mismas batas quirúrgicas que utilizaban para la curación de los pacientes en las operaciones quirúrgicas, aumentando así el riesgo de contagio y generando un aumento en la tasa de infecciones intrahospitalarias.

En conclusión, los internos además de estar sometidos a una sobrecarga laboral, estrés, depresión y agresiones verbales, deben de preocuparse por conseguir materiales de bioseguridad que el centro 
hospitalario debería brindarles en las cantidades necesarias que requieran.

De igual forma, el Ministerio de Salud y EsSalud, en concordancia con los manuales de bioseguridad que ellos mismos imponen tendrían que -como principal obligación- pedir un incremento de sus presupuestos para que se destine exclusivamente a la compra del suficiente equipo de bioseguridad que por lo menos si no reduce el contagio de enfermedades, pare el crecimiento de este.

\section{B) Capacitaciones}

Las capacitaciones, en cualquier ámbito laboral, son pieza clave para la realización de un adecuado desempeño de las labores asignadas a los trabajadores - estas variaran de acuerdo al cargo que ostente el empleado-. Así como para la obtención de resultados óptimos para el centro de trabajo. Pero, para todo lo relacionado con la salud pública y la atención médica.

No solo es necesario, sino que es de vital importancia; debido a que, no se está manipulando maquinaria o se están redactando informes o documentos, se está velando por vida humanas que se encuentran en un estado vulnerable. Por ello, las capacitaciones que se les debe impartir a todo el personal médico y con mayor énfasis a los internos de 
medicina -al ser principiantes en la práctica de la medicina-, tienen que ser constantes y directamente orientadas a la reducción de accidentes biológicos.

Entonces, los tipos de capacitaciones necesitadas deberían versar principalmente sobre bioseguridad, que es básicamente impartir medidas de seguridad contra riesgos biológicos contraídos por la constante exposición a virus, bacterias e infecciones que se encuentran en todo Hospital. Mismas que tienen que realizarse antes y durante todo el tiempo que dure el programa de internado médico.

Asimismo, cada Hospital debe de tener un manual que explique ampliamente cual será el accionar diario y el protocolo de bioseguridad. Todo esto, conforme con lo mencionado en los reglamentos de internado de las universidades y el inciso h) del artículo $21^{\circ}$ del Reglamento de internado médico en el seguro social de salud-EsSalud, "Usar convenientemente los equipos de protección y cumplir las normas de Prevención de accidentes y de Bioseguridad"

Por el contrario, los internos entrevistados afirman que no tuvieron capacitaciones en los centros hospitalarios, ni antes ni durante el período de prácticas y, al mencionarles sobre el manual del programa de internado-donde se encuentran las normas a seguir en cuanto a 
bioseguridad- su respuesta fue que jamás se les menciono de manual alguno.

\section{Tabla 3.5}

Capacitación recibida durante el Programa de Internado Medico

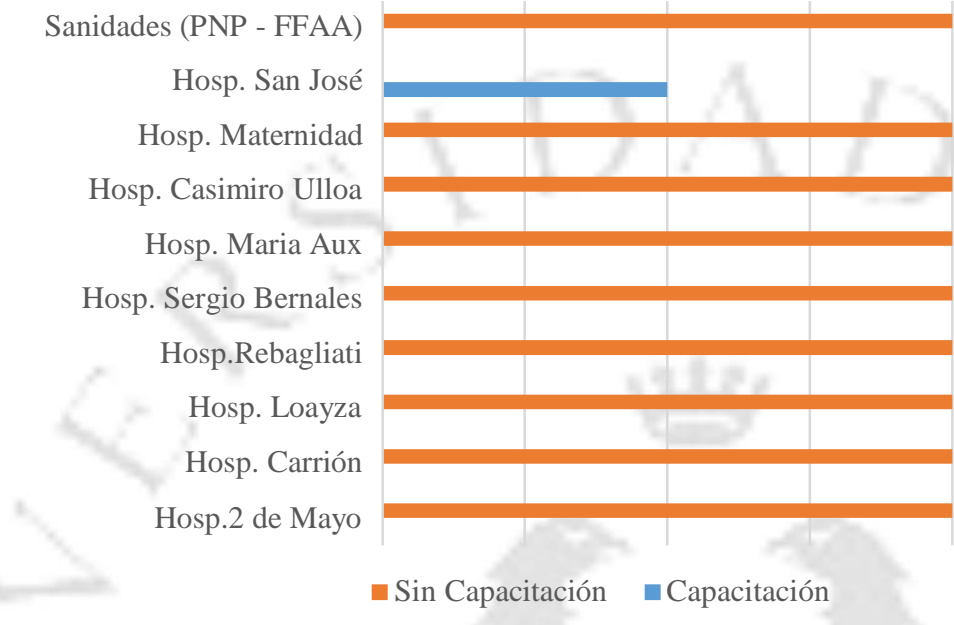

Información extraída de entrevistas realizadas a internos de medicina de 10 hospitales escuela (5 Hospitales del Ministerio de Salud, 5 Hospitales de EsSalud y 2 de sanidades) sobre si se recibieron capacitación durante el programa de internado.

Como se puede apreciar en la tabla superior, del total de Hospitales a los que los internos entrevistados pertenecen, solo en uno se recibió capacitación. Con lo que, se puede explicar la alta tasa de accidentes laborales que existen en los Hospitales, todos relacionados con la forma en los que se manipulaban los materiales utilizados para realizar curaciones a los pacientes -principalmente jeringas y escalpelos- 
En conclusión, los Hospitales al ser conscientes del grado de instrucción de los internos de medicina al comenzar el programa de internado médico, deberían poner no solo énfasis, sino exigir que estos pasen por talleres de capacitación en donde se les enseñe a manejar residuos biológicos, muestras y fluidos de los pacientes, materiales punzocortantes y etc., para no tener una tasa tan alta de accidentes laborales, tasa que seguirá aumentando por el nulo interés de los centros hospitalarios en capacitar a su personal.

\section{C) Vacunas}

Uno de los métodos de prevención de enfermedades más utilizado, es la inmunización activa o vacunación. La misma que, como lo recalca (Inga, Lopez, \& Kamiya Carlos, 2010) se caracteriza como la medida más eficiente para la prevención de determinadas enfermedades infecciosas; por esa razón, la vacuna contra el virus de la hepatitis B es uno de los requisitos indispensables para los estudiantes antes de empezar a realizar su práctica clínica.

Debido a que, la Hepatitis ocupa el primer lugar en la lista de enfermedades transmitidas en los Hospitales del Perú, tal como lo afirma el (Ministerio de Salud, 2014). Es más, La Organización Mundial de la Salud estima que entre el personal de salud la proporción 
de la carga mundial de la morbilidad atribuible a la exposición profesional es del $40 \%$ en caso de la Hepatitis B y C.

Por lo tanto, todos los reglamentos del programa de internado médico de las distintas universidades que cuentan con la carrera profesional de medicina; estipulan que, para obtener la calidad de "apto" y acceder a una plaza como interno de medicina, se debe de contar como mínimo con un certificado de salud -expedido por MINSA, EsSalud o Sanidades-, mismo que también señala el (Reglamento del Comité Nacional de Pregrado en Salud del SINAPRES , 2006, Art. 22), en el que se acredite su buena salud física y mental; además, esta certificación debe incluir el despistaje de tuberculosis y la vacuna contra hepatitis B.

Asimismo, los internos de medicina al estar siempre en contacto con objetos punzo-cortantes, se encuentran permanentemente proclives a experimentar lesiones; estas, están asociadas principalmente con la transmisión ocupacional del virus de la hepatitis B (VHB), virus de la hepatitis C (VHC) y virus de la inmunodeficiencia humana (VIH), pero también pueden estar implicadas en la transmisión de más de otros 20 patógenos

Entonces, se podría decir que, los internos de medicina estarían "totalmente" protegidos contra la Hepatitis. Sin embargo, se encuentran desprotegidos contra los otros 20 tipos de enfermedades que se pueden 
contraer en un Hospital, mismas que pueden variar entre uno y otro centro de atención de salud; ya que, hay enfermedades intrahospitalarias con mayor incidencia en ciertos hospitales. Por esa misma razón, los centros hospitalarios deberían brindarles a los internos vacunas para estos otros tipos de patógenos que pudieran contraer en sus instalaciones.

Para comprobar esto, se les pregunto a los entrevistados si recibieron en algún momento del transcurso del programa de internado médico alguna vacuna por parte de los hospitales escuela donde realizaban sus prácticas. De lo que se pudo concluir, que solo la mitad de los 12 hospitales a los que pertenecían los entrevistados recibieron vacunas aparte de la vacuna contra la Hepatitis.

\section{Tabla 3.6}

Vacunas puestas por los Hospitales Escuela

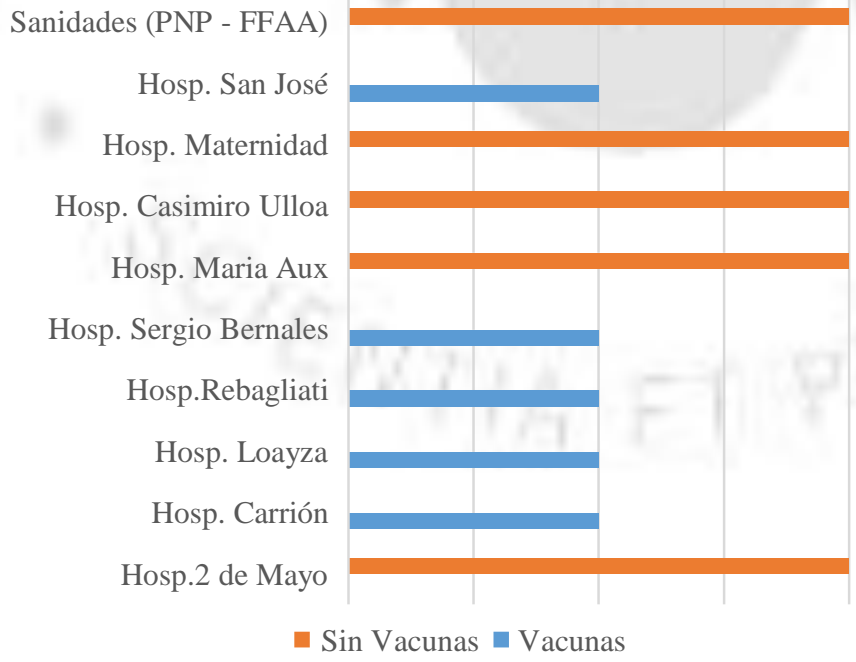

Información extraída de entrevistas realizadas a internos de medicina de 10 hospitales escuela (5 Hospitales del Ministerio de Salud, 5 Hospitales de EsSalud y 2 de sanidades) sobre si se les inyecto alguna vacuna antes de iniciar el programa. 
En conclusión, el certificado de vacunación contra la Hepatitis que presentan los internos antes de iniciar el programa de internado, es un excelente paso para la protección de estos ante la transmisión de enfermedades intrahospitalarias. Sin embargo, se los deja desprotegidos ante las decenas de otras enfermedades e infecciones que se presentan en sus centros de labores. Por ello, en mi opinión, se les debería exigir a los Hospitales que inoculen a los internos contra los demás tipos de patógenos que pudieran contraer en el ejercicio de sus funciones.

\section{D) Supervisión de Labores}

Si bien es cierto, la supervisión de las labores de los internos de medicina no es propiamente un método de prevención de transmisión de enfermedades, es una forma o manera de evitarlas. Conforme se detalla en todos los reglamentos del programa de internado de medicina -ya sea de EsSalud, MINSA, Sanidades o de las universidades-. Una de las funciones de los médicos contratados en los hospitales es la de actuar de docentes para los internos, y de esa manera supervisarlos, asesorarlos e instruirlos en la práctica de la medicina.

Es decir, los médicos residentes deben de supervisar y a la vez enseñar la manera correcta de atender a los pacientes, como realizar las curaciones, toma de muestras de fluidos, suturas, y demás tareas afines a la profesión. De esta manera, no solo se garantizaría una correcta 
tutoría a los practicantes, sino también se estaría reduciendo la tasa de accidentes laborales ocasionados por la inexperiencia de los internos.

Puesto que, al ser "controlados" sistemáticamente, el número y nivel de errores que están predispuesto a cometer, serían mínimos. Asimismo, la supervisión por parte de los médicos residentes enriquecería en forma sustancial los conocimientos de los practicantes pre profesionales en salud. Sin embargo, la realidad es otra, más de la mitad de hospitales a los que pertenecían los internos entrevistados no tiene médicos residentes supervisando la labor de los practicantes, y en el resto de hospitales, donde si existía supervisión, esta no era constante ni adecuada.

Tabla 3.7

Supervisión de las labores

Sanidades (PNP - FFAA)

Hosp. San José

Hosp. Maternidad

Hosp. Casimiro Ulloa

Hosp. Maria Aux

Hosp. Sergio Bernales

Hosp.Rebagliati

Hosp. Loayza

Hosp. Carrión

Hosp.2 de Mayo

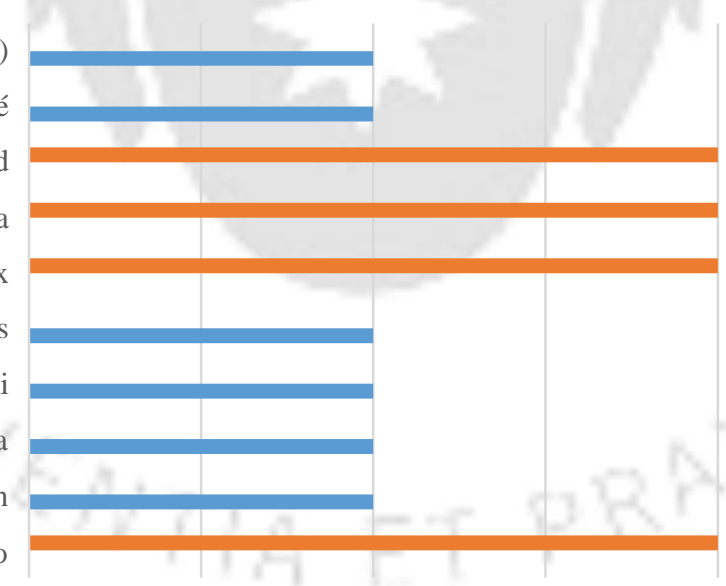

- Sin Supervisión $\quad$ Supervisión

Información extraída de entrevistas realizadas a internos de medicina de 10 hospitales escuela (5 Hospitales del Ministerio de Salud, 5 Hospitales de EsSalud y 2 de sanidades) sobre si sus labores son supervisadas por un médico residente o contratado. 
Como se puede evidenciar de la tabla superior, existe poca supervisión a los internos, lo que repercute directamente en su rendimiento y en el número de accidentes que puedan ocasionar a los pacientes y a sí mismos.

En conclusión, es imperativo que los Hospitales asignen un número de médicos residentes para supervisar y enseñar a los internos de medicina constantemente. Puesto que, de esa forma se reducirían los accidentes laborales, se atendería de una manera más eficiente a los pacientes, se utilizarían menos recursos para realizar las curaciones y los internos aprenderían la práctica de la medicina más rápida y adecuadamente, que es la función principal del programa de internado.

\section{E) Seguro contra Accidentes}

En virtud del Artículo $\mathrm{N}^{\circ} 42$ inciso 8 de la Ley $\mathrm{N}^{\circ} 28518$ “Ley sobre modalidades formativas", todas las empresas, en este casos los Hospitales escuela, tienen como obligación contratar un seguro contra accidentes para sus practicantes pre profesionales, que tenga una cobertura equivalente a catorce (14) subvenciones mensuales en caso de enfermedad y treinta (30) por accidentes. Si esta disposición no se cumple, se comete una infracción laboral conforme al inciso 5 del 
Artículo $52^{\circ}$ de la mencionada Ley, que establece lo siguiente: "No contratar un seguro que cubra los riesgos de enfermedad y accidentes o no asumir directamente el costo de estas contingencias".

Si bien es cierto, el seguro contra accidentes es un beneficio que se les brinda a todos los practicantes pre profesionales. Este, se torna indispensable para los internos de medicina, que debido a las características del trabajo que realizan, no contar con un seguro contra accidentes los pondría en desprotección frente a las altas posibilidades de contraer infecciones o enfermedades en los centros hospitalarios. No obstante, cabe mencionar que el seguro contra accidentes no es propiamente un método de prevención de enfermedades, pero si es una forma de protección frente a la adquisición de estas.

Sin embargo, la mayoría de Hospitales escuela -por no decir, la totalidad de ellos- no proporciona un seguro especializado contra accidentes. Como se puede apreciar en el grafico inferior, de todos los hospitales a los que pertenecen los internos entrevistados, solo uno de ellos otorga un seguro contra accidentes a los practicantes de medicina, situación que es alarmante; puesto que, los hospitales no solo comenten una infracción laboral al no brindar dicho seguro, sino que están poniendo en riesgo la vida de los internos. 
Tabla 3.8

Seguro otorgado por los Hospitales

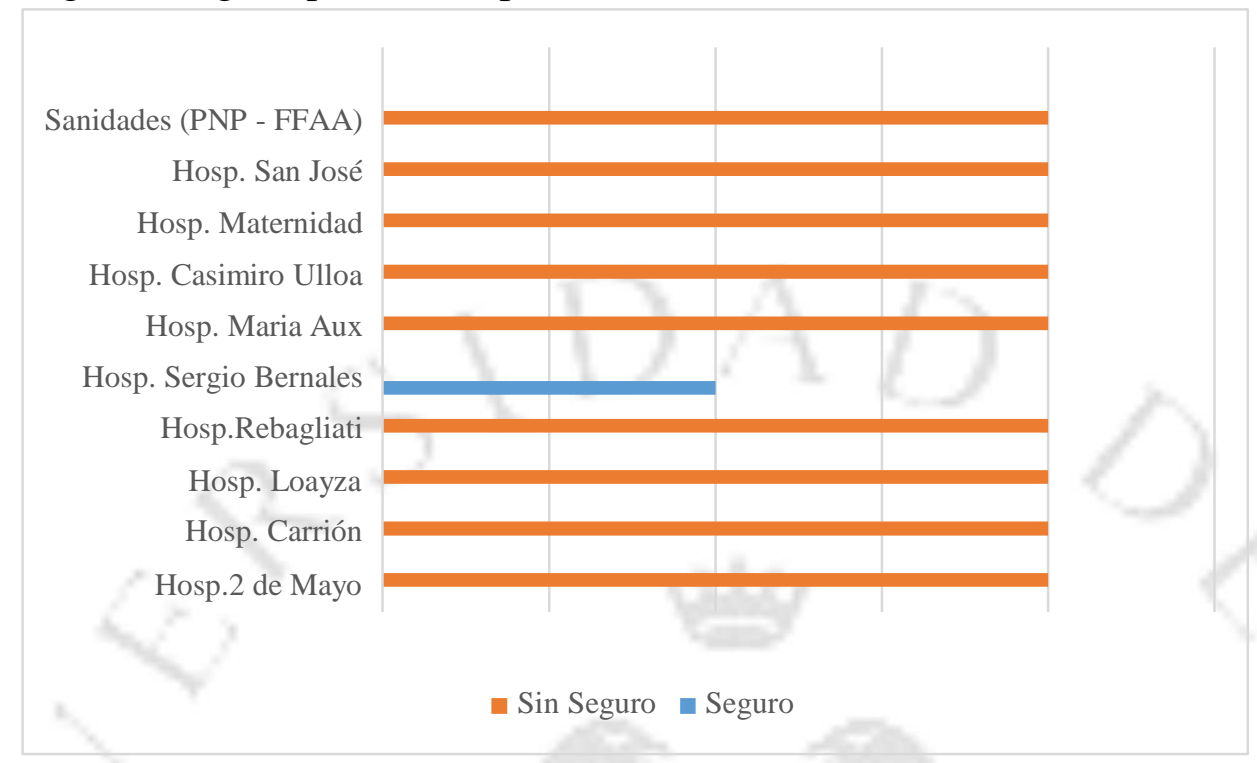

Información extraída de entrevistas realizadas a internos de medicina de 10 hospitales escuela (5 Hospitales del Ministerio de Salud, 5 Hospitales de EsSalud y 2 de sanidades) sobre si los Hospitales escuela les brindan un seguro contra accidentes.

Asimismo, en mi opinión la obligación que tienen los hospitales de brindar un seguro a los practicantes, en el caso de los internos de medicina, debería ser mejor especificada. Debido a que, como ya mencioné en párrafos anteriores, la labor que estos realizan no es la misma a labor que realizan los demás tipos de practicantes pre profesional; por ende, el seguro contra accidentes tendría que ser uno que se encuentra acorde a sus necesidades, que son las de prácticamente las de un trabajo de riesgo.

En conclusión, es imperativo que los hospitales subsanen esta omisión de no dar importancia a tan crucial aspecto, que es otorgar un seguro contra accidentes a los internos de medicina. Puesto que, como 
describí anteriormente, los internos de medicina se encuentran en una seria indefensión ante la contracción de infecciones hospitalarias y accidentes laborales.

\section{$\underline{\text { 3.3 Beneficios del Programa de internado médico }}$}

El programa de internado médico, así como tiene desventajas, que fueron descritas en párrafos anteriores, también tiene beneficios. Entre los cuales se encuentran, la subvención económica, la alimentación, por último, el control de asistencia/salida que sirve para contabilizar el tiempo permanecido diariamente en los hospitales y de esa manera cumplir con el máximo de horas establecidas semanalmente para el cumplimiento del programa.

En virtud a ello, desarrollare cada una de las ventajas señaladas para comprobar si efectivamente son beneficiosas para los internos, o implican un problema para ellos.

\subsubsection{Subvención económica}

Los practicantes pre y profesionales reciben como contraprestación por las funciones realizadas en sus centros de formación profesional una "subvención económica”, llamada así por no tener carácter remunerativo; puesto que, no existe una relación laboral 
entre las partes debido a que se trata de un convenio de prácticas cuyo fin es la instrucción y capacitación de los beneficiarios. Asimismo, dicha subvención no puede ser menor a una remuneración mínima vital, esto conforme con el Artículo $\mathrm{N}^{\circ} 45$ de la Ley de modalidades formativas, que señala lo siguiente: "la subvención económica mensual no puede ser inferior a una Remuneración mínima cuando la persona en formación cumpla la jornada máxima prevista para cada modalidad formativa"

A pesar de esto, más del $90 \%$ de los internos de medicina no recibe como pago el monto señalado en la mencionada ley. La mayoría de ellos percibe un monto menor o igual a $\mathrm{S} / .400 .00$ soles o en el peor de los casos absolutamente nada. Esto se sustenta en las entrevistas realizadas, en donde se puede corroborar que la suma otorgada a los practicantes en salud en ninguno de los casos es equivalente a una RMV. 
Tabla 3.9

Monto de la Remuneración otorgada a los internos

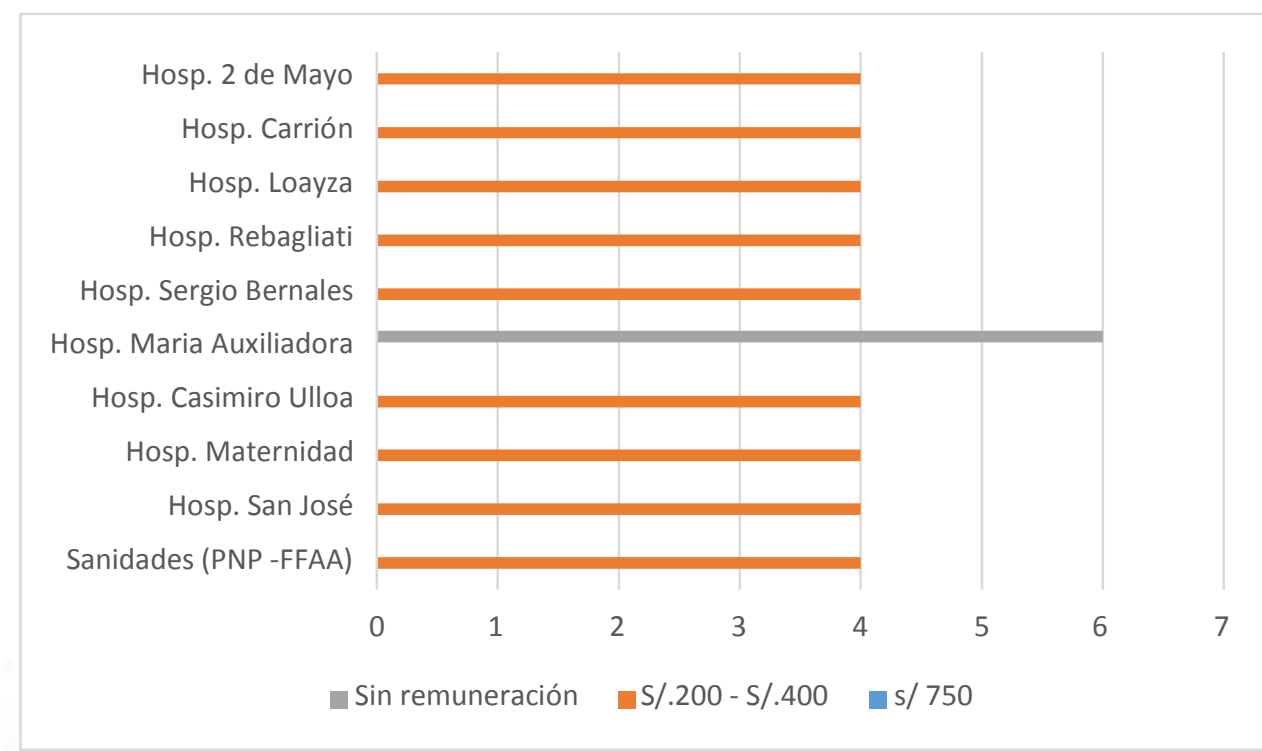

Información extraída de entrevistas realizadas a internos de medicina de 10 hospitales escuela (5 Hospitales del Ministerio de Salud, 5 Hospitales de EsSalud y 2 de sanidades) sobre el monto de la remuneración recibida por los internos de medicina.

Si bien es cierto, la capacitación recibida por parte de doctores experimentados en la práctica de la medicina es el fin supremo del programa de internado médico; la subvención también es parte de esencial de este, además de ser un derecho reconocido por la Ley de modalidades formativas.

Es así que, el no concederla, es considerado una infracción; además de perjudicar a los internos, que deben hacer grandes esfuerzos económicos para cumplir con las exigencias del citado programa. Por ejemplo, cubrir cuotas de movilidad, alimentación y equipamiento 
desechable de bioseguridad que no les son brindados en los centros de salud. Entonces, además de tener que sufrir por todas las deficiencias del internado, en aras de extender sus conocimientos, deben de saldar costos de los que se deberían de encargar las instituciones médicas para las que laboran.

En conclusión, este llamado "beneficio" se convierte en una carga para los practicantes causándoles un perjuicio económico, al tener que solventar gastos que tendrían que ser asumidos por sus centros de formación profesional y no por ellos mismos, que supuestamente son los "beneficiarios" de este servicio.

\subsubsection{Control de Asistencia}

El control de asistencia, tiene como fin principal contabilizar las horas permanecidas por los internos de medicina en los Hospitales, y de esa manera controlar el cumplimiento de las 6 horas máximas diarias, 36 semanales y 150 mensuales incluidas las guardias nocturnas, conforme al Artículo $N^{\circ} 3$ inciso 1) del Decreto Supremo Nº03-2008TR.

Es por ello que, a manera de comprobar lo anteriormente descrito, se entrevistó a un número de practicantes de medicina de distintos centros hospitalarios de la ciudad de Lima. De lo cual se pudo corroborar que en la mayoría de ellos existe un control de asistencia 
físico que permite verificar las horas laboradas, como se puede apreciar en la siguiente tabla.

\section{Tabla 3.10}

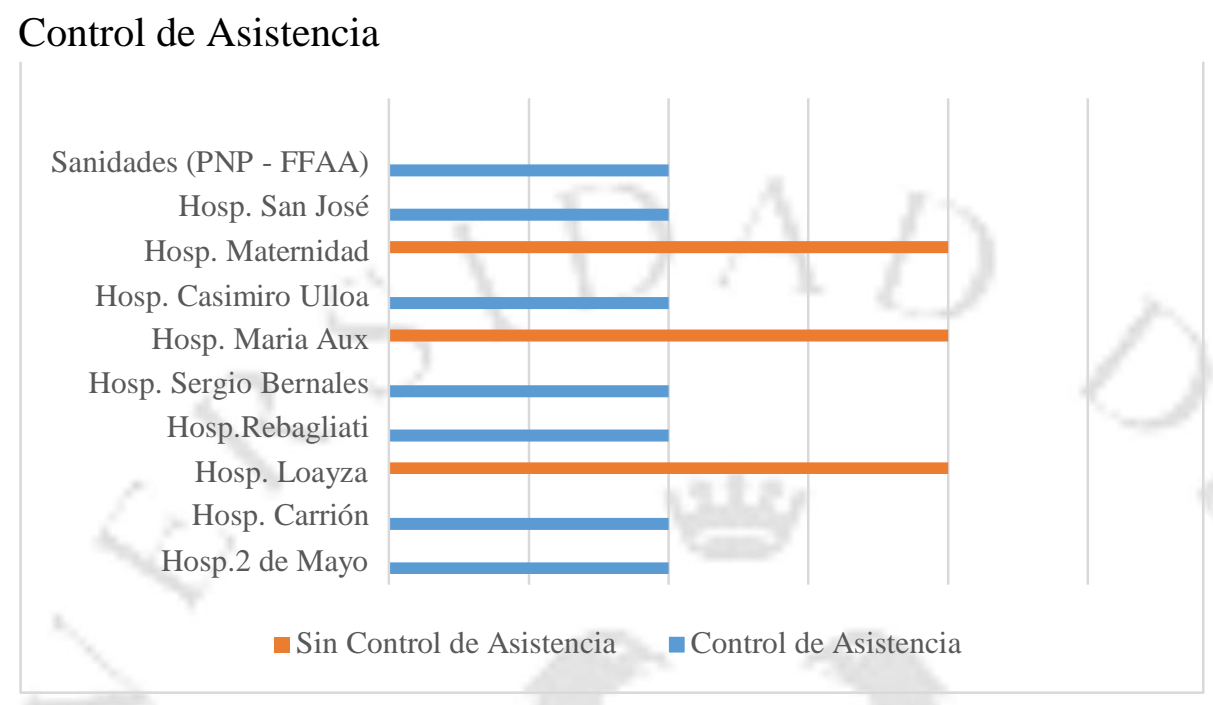

Información extraída de entrevistas realizadas a internos de medicina de 10 hospitales escuela (5 Hospitales del Ministerio de Salud, 5 Hospitales de EsSalud y 2 de sanidades) sobre si pasan control de asistencia en los Hospitales Escuela.

Entonces, este control de horas podría catalogarse como un beneficio; ya que, ayudaría a los internos a verificar que sus horas estén siendo correctamente contabilizadas para obtener el certificado de culminación efectiva del programa de internado. Igualmente, ayudaría a los médicos encargados a tener una mejor supervisión de los internos.

Pese a ello, el control de asistencias resulta "inservible", debido a que no se cumple con lo dispuesto por el Decreto Supremo. Y es que, las horas trabajadas exceden en un gran porcentaje a las horas 
establecidas por el dispositivo legal. Dado que existe una alta carga laboral que obliga y a la vez "justifica" el exceso de horas de práctica.

En conclusión, independientemente de que exista o no una supervisión de asistencias, no se cumple con la norma establecida, generando que dicho control no sea un beneficio para los internos, sino más bien para los hospitales, que la utilizarían como prueba para suspender a los practicantes por no asistir en los horarios establecidos.

\subsubsection{Alimentación}

Como parte del programa de internado se encuentran las guardias obligatorias en emergencia, lo que fuerza a los internos a permanecer largas horas en los hospitales -generalmente en las madrugadas- muy aparte del horario del internado.

Normalmente, estas guardias comienzan en las noches y terminan al día siguiente; por ello, según el Artículo $\mathrm{N}^{\circ} 20$ del Reglamento de Internado Médico en el Seguro Social de Salud EsSalud, los practicantes deben recibir la misma alimentación que se ofrece al personal de guardia del centro asistencial de salud. Más allá de que lo disponga o no dicho reglamento, los Hospitales escuela tendrían que suministrarles los alimentos necesarios para que los internos se encuentren bien alimentados y así poder soportar las extensas horas de guardia. 
Es así que, mediante las entrevistas realizadas, se pudo corroborar que la mayoría de los Hospitales otorgan alimentos a los internos durante el tiempo que se encuentren cubriendo las guardias en el servicio de emergencia, como se puede visualizar en la siguiente tabla:

\section{Tabla 3.11}

Alimentos brindados por los Hospitales

Sanidades (PNP - FFAA)

Hosp. San José

Hosp. Maternidad

Hosp. Casimiro Ulloa

Hosp. Maria Aux

Hosp. Sergio Bernales

Hosp.Rebagliati

Hosp. Loayza

Hosp. Carrión

Hosp. 2 de Mayo

$$
\text { - Sin Refrigerios } \quad \text { Refrigerios }
$$

Información extraída de entrevistas realizadas a internos de medicina de 10 hospitales escuela (5 Hospitales del Ministerio de Salud, 5 Hospitales de EsSalud y 2 de sanidades) sobre si se les brindaba algún tipo de alimento (desayuno, almuerzo, cena) durante el transcurso del día.

Por otra parte, de las mismas entrevistas se pudo llegar a la conclusión de que, en los Hospitales donde si se les ofrecía algún tipo de alimento a los internos - ya sea desayuno, almuerzo o cena-estos muchas veces se encontraban en pésimo estado. 
Es por ello que, debería ser una obligación de los centros de salud dar todo tipo de alimentos a los internos, y sobretodo que estos se encuentren en óptimas condiciones; de no ser así, se estaría poniendo en grave riesgo la salud de los practicantes que tienen que permanecer atendiendo a los pacientes muchas veces sin ingerir ningún tipo de comida, lo que podría provocar desvanecimientos por la falta de nutrientes ante tal tipo de esfuerzo físico y mental.

En conclusión, este beneficio no es correctamente concedido ni en todos los hospitales ni a todos los internos, por eso se tendría que establecer un plan de alimentación para los practicantes de medicina, que les permita alimentarse adecuadamente y de esa manera poder soportar las exigencias del programa de internado, que como se ha descrito a lo largo de esta tesis son muchas.

\section{Conclusiones Generales:}

Como he descrito a lo largo de este capítulo, los problemas que tienen que afrontar los practicantes de medicina son muchos más que los beneficios brindados por el programa de internado médico. Todo esto, a causa del lamentable descuido por parte del Estado; a pesar, de la existencia de distintas normas "supuestamente" encargadas de velar por las necesidades de estos, que al final nunca se aplican, teniendo como consecuencia la desprotección total de sus derechos. 
Asimismo, resulta contradictorio que siendo el Estado el mayor beneficiado con la labor que realizan los practicantes, sea a la vez el menos interesado en tratar de mejorar sus condiciones. Y es que, los internos muchas veces suplen las funciones que los doctores residentes no pueden $-\mathrm{O}$ no quieren- realizar, además de trabajar un número de horas excesivas para su calidad de practicantes, soportar condiciones austeras, trato poco amable, recorte de derechos y exposición a enfermedades. Formando así, la mayor y la más sacrificada fuerza laboral del sector salud.

Por consiguiente, en mi opinión, se necesita de la existencia de un dispositivo legal que detalle exactamente qué beneficios deben de tener los practicantes, las obligaciones que deben cumplir, la forma de desarrollo del programa y las sanciones aplicables; para que de esa manera se subsane la gran omisión hacia este grupo fundamental para la protección médica de la sociedad. 


\section{Capítulo IV}

\section{Propuesta de un Proyecto de Ley sobre Beneficios}

\section{Laborales Específicos Para los Practicantes Pre}

\section{PROFESIONALES EN SALUD}

En vista de todas las falencias que posee el programa de internado médico en la ciudad de Lima, sugiero la siguiente lista de propuestas que ayudaran a sentar las bases para la elaboración de un proyecto de Ley que otorgue mejores y mayores beneficios laborales para los internos de medicina. 


\section{DEL SEGURO CONTRA ACCIDENTES:}

"Los Centros hospitalarios que funjan como Hospitales escuela deberán otorgar a los internos de medicina un seguro médico contra accidentes que cubra cualquier tipo de incidente biológico, transmisión de enfermedades infecto contagiosas y demás accidentes consecuencia del ejercicio de su profesión. Asimismo, se deberá garantizar la cobertura de hospitalización de los internos (en caso sea necesario)"

- Esta propuesta se fundamenta en la necesidad de proteger a todos los practicantes de medicina de los focos infecciosos que existen en los hospitales en los cuales desarrollan sus prácticas. Cabe acotar que, el seguro que se les debe prestar tendrá que contar con una póliza especifica que cubra las eventualidades que solo se pueden suscitar en mencionados ambientes; por lo que, un seguro básico no sería lo más adecuado para cubrir las necesidades mínimas de los internos de medicina.

\section{DE LAS CAPACITACIONES:}

"Previo al comienzo del programa de internado médico se deberá de brindar una capacitación introductoria a todos los internos, que serán seguidas por capacitaciones mensuales. estas 
versarán sobre temas de bioseguridad, disposición de materiales de desecho bioquímico, manipulación de elementos quirúrgicos y protocolos de atención a los pacientes. De la misma manera, por cada cambio de módulo de especialidad (por lo general se realiza cada 3 meses) se deberán de realizar capacitaciones específicas de acuerdo al módulo correspondiente"

- Propuesta se funda en la imperante necesidad de capacitar a los internos previamente al comienzo de sus labores en los Hospitales. De esa manera se trata de minimizar el número de accidentes productos de la poca experiencia que dichos practicantes poseen. Asimismo, las capacitaciones deben ser periódicas conforme al cambio de módulo de enseñanza y versarán tanto en temas de atención a los pacientes como en manipulación del material diario de trabajo.

\section{DE LA CERTIFICACIÓN DE LOS HOSPITALES ESCUELA:}

"Cada uno de los Centros Hospitalarios que deseen ostentar la calidad de Hospitales escuela deberá poseer una certificación que acredite lo siguiente:

Buen estado de sus instalaciones.

Ambientes destinados únicamente para el uso de los internos (descanso, alimentación, estudio). 
Número suficiente de Médicos contratados que sirvan como supervisores/docentes de los internos.

Equipos tecnológicos médicos en óptimas condiciones.

Material de bioseguridad."

- La certificación de los Hospitales Escuela es tan necesaria como las capacitaciones, pues esto motiva a dichos Nosocomios a mejorar sus condiciones; al no hacerlo, no podrán contar con la calidad de Centros de Enseñanza y por ende no contarán con el Programa de Internado / Internos de medicina, que es la mayor fuerza laboral con la que cuentan, sin la cual no podrían atender la gran demanda de pacientes que reciben diariamente.

\section{DE LA VACUNACIÓN OBLIGATORIA A LOS INTERNOS DE}

\section{MEDICINA}

"Los internos de medicina, antes de iniciar el programa de internado médico deberán ser inoculados ante todo tipo de enfermedades infecto contagiosas por el Hospital escuela al cual fueron asignados; asimismo, estas vacunas no deben tener ningún costo para los internos."

- La inoculación a los internos, contra todo tipo de enfermedades que conformen los focos infecciosos de los Hospitales es una exigencia que se debe cumplir antes del inicio del Programa de 
internado; sin embargo, la carga monetaria que implica contar con todas las vacunas debe ser asumida por el Centro Hospitalario al cual cada interno ha sido asignado, pues los Hospitales son los mayores beneficiados con el trabajo que realizan los practicantes, que como ya mencioné son su principal fuerza laboral.

\section{DEL HORARIO DE PRACTICAS PRE PROFESIONALES DE LOS INTERNOS DE MEDICINA}

"El horario de prácticas pre profesionales de internos de medicina será de diez (10) horas diarias, sesenta (65) horas semanales y doscientas noventa (290) horas mensuales. Asimismo, solo podrán ser asignados a guardias nocturnas como máximo una vez por semana para las cuales deberán contar con un descanso previo y posterior de seis (06) horas"

- Las practicas pre profesionales en salud, por su naturaleza necesitan ser realizadas en un horario de mayor duración a diferencia de cualquier otro tipo de prácticas, esto debido a las exigencias que implican formarse como Médico. Por ello, seis (06) horas diarias no son suficientes para cumplir con su cometido. Bajo ese contexto, propongo que estas tengan una mayor extensión acorde a la realidad, permitiendo así una formación adecuada del interno de medicina. 


\section{DEL SEGURO POR RESPONSABILIDAD CIVIL:}

“Todo Centro Hospitalario que brinde sus instalaciones para el desarrollo del Programa de Internado Médico deberá proporcionar a los practicantes pre profesionales/internos de medicina un seguro por responsabilidad civil que permita cubrir los gastos generados ante cualquier tipo de accidente ocasionado a los pacientes. Por ello, los Hospitales deben de contar con un fondo que sirva como protección tanto para los pacientes como para los internos “

- Esta propuesta se origina en la falta de regulación de todos y cada uno de los reglamentos del programa de internado de medicina de las distintas universidades de Lima, reglamentos de internado de los Hospitales escuela y en el nulo interés por parte de los legisladores de normar sobre este vacío legal; asimismo, se fundamenta en la falta de desprotección a los pacientes que diariamente se atienden en los principales hospitales de la ciudad con la idea de ser atendidos por los mejores médicos del país cuando en realidad, serán atendidos por internos de medicina que aún no cuentan con la experiencia necesaria para diagnosticar y/o proporcionar las atenciones necesarias. Por ello, los Hospitales deben de otorgar a los internos de medicina un seguro por responsabilidad civil que debe ser respaldado por 
un fondo económico que indemnice a los pacientes y que cubra los gastos en los que estos incurran.

\section{DE LA ALIMENTACIÓN}

“Los Hospitales Escuela proporcionaran alimentación a los internos de medicina mientras estos se encuentren laborando en sus instalaciones. Esta debe constar de un desayuno y un almuerzo diario. En el caso de los internos que tengan turno de guardia nocturna, se les deberá proporcionar la cena"

- Los internos de medicina pasan la mayor parte del día en las instalaciones de los Hospitales formándose y capacitándose en el área práctica de la carrera de medicina; por ello, necesitan de una alimentación que les permita resistir las largas horas de labores, la cual debe ser brindada por el Centro Hospitalario. 


\section{CONCLUSIONES:}

A continuación, detallare las conclusiones a las que he llegado a partir de la investigación que realicé sobre el Programa de Internado Médico y su desarrollo:

- El Programa de internado medico en el Perú y sobretodo en la Ciudad de Lima, es deficiente en todos los aspectos que lo conforman, en el aspecto operativo como normativamente. Ello, debido a que no cuenta con una estructura uniforme ni con reglamentos universitarios estandarizados que permitan un control homogéneo del programa.

- Las normas jurídicas que regulan las practicas pre profesionales no realizan una distinción -necesaria e indispensable- con respecto a los practicantes de ciencias de la salud. A su vez, la normativa específica creada a partir de la problemática referente al programa de internado, no se encuentra correctamente establecida, generando así una legislación deficiente con relación al Programa de Internado Médico.

- No existe capacidad logística suficiente por parte del Ministerio de Salud y de EsSalud en brindar facilidades a los Centros 
Hospitalarios para mejorar sus condiciones estructurales, operativas y de seguridad, que les permita funcionar de manera adecuada y ofrecer una atención medica de calidad; así como, otorgar un apropiado ambiente para la formación de los internos de medicina.

- Los Hospitales escuela no cumplen con los estándares mínimos de bioseguridad y protección, poniendo en riesgo sistemático a los internos de medicina y a los pacientes, exponiéndolos al contagio latente de enfermedades y accidentes.

- La inexistencia de capacitaciones a los internos de medicina ha generado que estos no se encuentren lo suficientemente preparados para atender las emergencias médicas y la atención a los pacientes de manera correcta.

- La falta de un seguro por responsabilidad civil que cubra las impericias cometidas por parte de los internos de medicina, perjudica a los pacientes, lo que se podría subsanarse si existiera una normativa que lo regule. 


\section{REFERENCIAS}

Arias Odon , F. (1999). El proyecto de investigacion - guia para su elaboracion. Recuperado de http://www.smo.edu.mx/colegiados/apoyos/proyectoinvestigac ion.pdf

Arroyo, J. (2007). Analisis y propuesta de criterios de acreditacion de campos clinicos de practica en la formacion de pre y postgrado de los profesionales de la salud. Recuperado de [Version PDF]: http://www.minsa.gob.pe/portalweb/01institucional/institucion _3.asp?sub5=2

Behar Rivero, D. (2008). Metodologia de la Investigacion. Cuba: Shalom.

Gonzales Ramirez, L., \& De Lama Laura, M. (2010).

Desnaturalizacion en las relaciones laborales: situaciones de simulacion y fraude en los contratos de trabajo, tercerizacion, intermediacion, modalidades formativas y otros ( 1 a ed.). Lima: Gaceta Juridica.

Inga, E., Lopez, G., \& Kamiya Carlos. (Enero-Marzo de 2010). Accidentes biologicos en estudiantes de medicina de una universidd peruana: prevalencia, mecanismos y factores de riesgo. Anales de la Facultad de Medicina de la Universidad Mayor de San Marcos, 71(1), 37-42. Recuperado de http://www.scielo.org.pe/scielo.php?script=sci_arttext\&pid=S1 025-55832010000100007

Ley 17.132. (24 de enero de 1967, Art. 41). Boletin Oficial de la Republica Argentina. Buenos Aires, Argentina.

Ley 26.427. (26 de noviembre de 2008, Art. 2). Boletin Oficial de la Republica Argentina. Buenos Aires, Argentina.

Ley $\mathrm{N}^{\circ}$ 28518. (24 de Mayo de 2005, Art. 8). Diario Oficial del Estado Peruano. Lima, Peru.

Lopez Noguero, F. (2002). El analisis de contenido como metodo de investigacion - guia para su elaboracion. Revista de Educacion , 167-179.

Ministerio de Salud . (2004). Manual de Bioseguridad - Sistema de Gestion de calidad del PRONAHEBAS: Programa Nacional de Hemoterapia y Bancos de sangre. Lima, Peru : Minsa. 
Recuperado de

http://www.minsa.gob.pe/dgsp/observatorio/documentos/infec ciones/MANUAL\%20DE\%20BIOSEGURIDAD.pdf

Ministerio de Salud. (2006). Diagnostico Fisico funcional de infraestructura, equipamiento y mantenimiento de los Hospitales e Institutos del Ministerio de Salud. Lima: Minsa.

Ministerio de Salud. (2014). Informe Anual de actividades del comite de control y prevencion de infecciones intrahospitalarias Instituto Nacional de Enfermedades Neoplasicas "EDUARDO CACERES GRAZIANI". Lima, Peru : MINSA. Recuperado de http://www.inen.sld.pe/portal/documentos/pdf/comite_prevenc ion_infecciones/14012015_CCPIH_INFORME\%20ANUAL.p df

Ministerio de Salud. (22 de Abril de 2016). www.minsa.gob.pe. Recuperado de

http://www.minsa.gob.pe/portalweb/01institucional/institucion _3.asp?sub5=2

MINSA-DGGDRH. (9 de marzo de 2015). Numero total de postulantes y adjudicados de medicina: periodo 2013-2015 (informacion obtenida a traves de la solicitud de acceso a la informacion $\mathrm{N}^{\circ}$ 15-003825). Lima, Peru.

Montenegro Idrogo, J., Montañez Valverde, R., \& Sanchez Tonohueye, J. (2012). Sobredemanda del Campo Clinico para estudiantes de medicina. Revista peruana de medicina experimental y salud publica, 155-157.

Proexpansion. (2014). Residuos solidos: conoce la unica planta de tratamiento de residuos hospitalarios en el Peru. Recuperado de http://proexpansion.com/en/articles/746-residuossolidosconoce-la-unica-planta-de-tratamiento-deresiduoshospitalarios-en-el-peru

Reglamento del Comite Nacional de Pregrado en Salud del SINAPRES . (2006, Art. 22). Lima, Peru.

Reglamento del Comite Nacional de Pregrado en Salud del

SINAPRES. (2006, 1era disposicion complementaria). Lima, Peru.

Reglamento del Comite Nacional de Pregrado en Salud del SINAPRES. (2006, Art 21). Lima, Peru. 
Reglamento del Comite Nacional de Pregrado en Salud del SINAPRES. (2006, Art.1). Lima, Peru. 


\section{BIBLIOGRAFÍA}

Behar Rivero, D. S. (2008). Introducción a la Metodología de la Investigación. Editorial Shalom. ISBN 978-959-212-773-9.

Castrillón, J. J. C., Ceron, A. C., Collazos, A. K., Molina, A. M., Osorio, J., Ospina, A., ... \& Zambro, O. E. (2012). Factores que inciden en la motivación académica en un programa de medicina, Manizales, Colombia, 2010. Archivos de Medicina (Manizales), 12(1), 46-61.

Centro de Investigaciones Judiciales (CIJ). (2007). Guia Metodologica para la elaboracionde iniciativas legislativas. [Version PDF]. Recuperado de http://www2.congreso.gob.pe/sicr/cendocbib/con2_uibd.nsf/ E1E327FCD2D857F9052577370044EB0D/\$FILE/Guiaparal apresentaciondeiniciativasPJ.pdf

Cortijo, J., Gómez, M., \& Samalvides, F. (2010). Cambios en conocimientos, actitudes y aptitudes sobre bioseguridad en estudiantes de los últimos años de Medicina. Revista Médica Herediana, 21(1), 27-31.

Decreto $\mathrm{N}^{\circ}$ 2376. (01 de Julio de 2010). Gobierno de ColombiaMinisterio de la Proteccion Social. Bogota, Colombia.

Decreto Supremo N 106-2012-EF. (29 de Junio de 2012). Gobierno del Estado Peruano - Diario Oficial el Peruano. Lima, Peru.

Extento $\mathrm{N}^{\circ}$ 254. (09 de Julio de 2012). Gobierno de Chile Subsecretaria de Redes Asistenciales . Santiago, Chile.

Fernandez, R. J. (1987). El Estado Empresario. [Version PDF]. Recuperado de https://archivos.juridicas.unam.mx/www/bjv/libros/3/1027/1. pdf

Martínez, M. (2006). La investigación cualitativa. Revista de investigación en psicología, 9(1), 123-146.

Ministerio de Salud - Hospital Nacional Sergio Bernales. (2015). Reglamento de Internos de Ciencias de la Salud .

Ministerio de Salud - Hospital San Juan de Lurigancho. (2013). 
Reglamento de Internado.

Ministerio de Salud. (2007). Normas legales y administrativas que regulan el trabajo y la carrera de los profesionales de la salud en el sector salud. (2da edicion). [Version PDF]. Recuperado de

ftp://ftp2.minsa.gob.pe/normaslegales/boletines/ProfSalud_2 ED.pdf

Orellana-Peña, C., Olmos-Olmedo, J. M., \& Rebolledo-García, E. (2011). Sobreexposición de los pacientes en hospitales docentes: la experiencia en un servicio de medicina. Persona y Bioética, 15(1), 78-89.

Palacios, R. M. (2006). Investigación cualitativa y cuantitativa Diferencias y limitaciones. PIURA PERU.

Quintana, A. (2006). Metodologia de investigacion cualitativa. En Psicologia: Topicos de actualidad. [Version PDF].

Recuperado de http://cienciassociales.webcindario.com/PDF/Cualitativa/Inv _quintana.pdf

Ramírez, M. (2008, September). Expectativas profesionales de internos de medicina y su inclinación por la atención primaria de salud. In Anales de la Facultad de Medicina (Vol. 69, No. 3, pp. 176181). UNMSM. Facultad de Medicina.

Rey De Castro Mujica, J., \& Vizcarra Escobar, D. (2003). Frecuencia de síntomas del Síndrome apnea hipopnea del sueño e insomnio en médicos de una clínica privada peruana. Revista Medica Herediana, 14(2), 53-58.

Roth, A. E. (1984). The evolution of the labor market for medical interns and residents: a case study in game theory. The Journal of Political Economy, 991-1016.

Sogi Uematsui, C., Zavala Sarrio, S., Delgado Vásquez, A., \& Cárdenas Díaz, M. (2010). Los problemas éticos en la práctica clínica de médicos jóvenes peruanos. Acta Médica Peruana, 27(4), 227232.

Taype-Rondán, Á., Tataje Rengifo, G., Arizabal, A., \& Alegría Hernández, S. (2016, January). Percepción de médicos de una universidad de Lima sobre su capacitación en procedimientos 
médicos durante el internado. In Anales de la Facultad de Medicina (Vol. 77, No. 1, pp. 31-38). UNMSM. Facultad de Medicina.

Trabajo, D. D. (2013). Código del trabajo. Santiago: Gobierno de Chile, Dirección del Trabajo.

Universidad San Martin de Porres. (2008). Reglamento de Internado Facultad de MedicinaHumana . 
ANEXOS 


\section{ANEXO $\mathbf{N}^{\circ}$ 1: ENTREVISTAS}

Como medio para recabar información detallada de las condiciones del Programa de Internado, realice una serie de entrevistas a un grupo limitado de internos de medicina (uno de cada hospital escuela), las cuales constaban principalmente en detallar su experiencia en los Centros Hospitalarios.

Dichas entrevistas constaban en señalar en que Hospital o Hospitales desarrollaron el programa de internado, si fueron vacunados por tal institución, el horario de prácticas, horario de guardias y si se les proporciono un ambiente óptimo para el descanso, si recibieron algún tipo de alimento durante su jornada de labores, si se les impartieron algún tipo de capacitaciones, si eran supervisados en la realización de labores, si contaban con un seguro brindado por la universidad o centro de prácticas, si recibían una RMV, si existe un control de asistencia, si reciben materiales de bioseguridad, y que por ultimo mencionen si habían tenido algún tipo de accidente laboral en el ejercicio de sus prácticas y cuál era el trato recibido por parte de sus superiores.

Las respuestas obtenidas por parte de 12 internos de medicina de 12 Hospitales Escuela distintos (5 del Ministerio de Salud, 5 de EsSalud y 2 de sanidades, se encuentran recopiladas en el siguiente cuadro: 


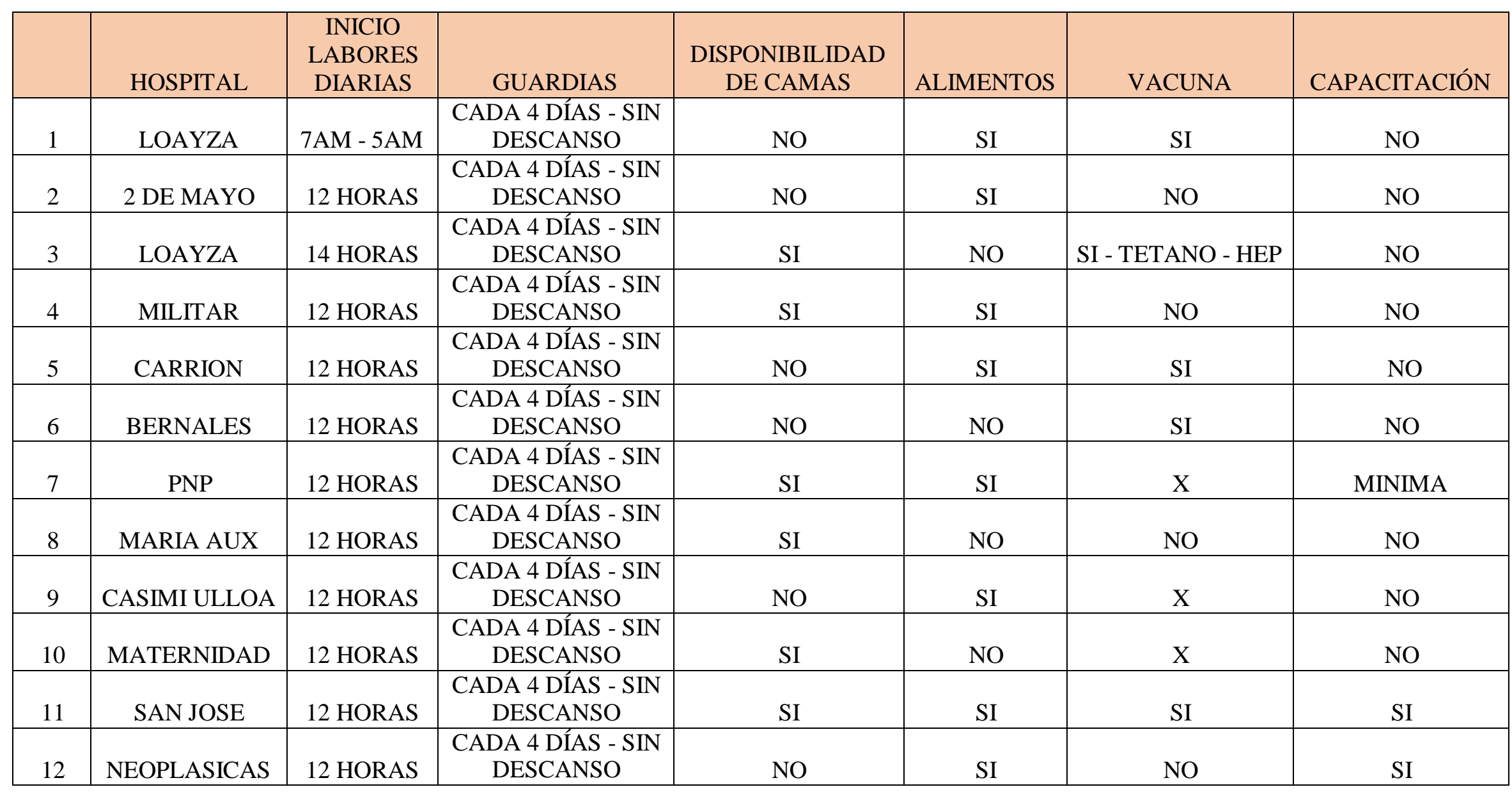




\begin{tabular}{|c|c|c|c|c|c|c|c|}
\hline & HOSPITAL & SUPERVISIÓN & SEGURO & RMV & MATERIALES & ASISTENCIA & AÑO \\
\hline 1 & LOAYZA & SI & SI & MENOR & NO & NO & 2013 \\
\hline 2 & $2 \mathrm{DE}$ MAYO & NO & NO & MENOR & A VECES & SI & 2015 \\
\hline 3 & LOAYZA & SI & NO & MENOR & NO & NO & 2015 \\
\hline 4 & MILITAR & SI & $\mathrm{NO}$ & MENOR & SI & SI & 2014 \\
\hline 5 & CARRION & SI & NO & MENOR & SI & SI & 2014 \\
\hline 6 & BERNALES & SI & SI & MENOR & NO & SI & 2015 \\
\hline 7 & PNP & SI & NO & MENOR & NO & SI & 2015 \\
\hline 8 & MARIA AUX & NO & NO & NO & NO & NO & 2015 \\
\hline 9 & $\begin{array}{l}\text { CASIMI } \\
\text { ULLOA }\end{array}$ & NO & NO & MENOR & NO & SI & 2015 \\
\hline 10 & MATERNIDAD & NO & NO & MENOR & NO & NO & 2014 \\
\hline 11 & SAN JOSE & SI & NO & 200 & SI & SI & 2014 \\
\hline 12 & NEOPLASICAS & NO & NO & MENOR & NO & NO & 2015 \\
\hline
\end{tabular}


De tales entrevistas pude extraer los siguientes alarmantes testimonios que son una prueba más de la deficiencia del programa de internado; así mismo, cabe mencionar que en prácticamente todas las entrevistas se repetía prácticamente la misma situación, por ello decidí solo seleccionar algunas:

- "El horario de entrada es a las 6 am y de salida a las 7 pm, pero si fui asignada a guardia, normalmente empieza una hora después o inmediatamente; así que, me tengo que quedar hasta el día siguiente que termina a las 6 am y empezar otra vez con el horario normal de internado, ósea trabajo 36 horas seguidas prácticamente sin descanso) “

- "En el Hospital Sergio Bernales en donde laboro no hay un cuarto para el descanso durante las guardias, tenemos que dormir en sillas en mal estado. El cuarto que existía para descansar fue clausurado por que encontraron a internos teniendo relaciones sexuales, por ese hecho nos hemos visto perjudicados todos"

- "En varias oportunidades he visto como mis compañeros derramaron sangre a la hora de su extracción, en otra ocasión confundieron muestras de sangre de un paciente con Sida y paciente sin tal enfermedad"

- "Por lo menos me he cortado unas veinte veces con los escápelos y pinchado unas cuantas más con las agujas” 
- " "el trato que nos dan los médicos residentes y encargados es de lo peor, todo el tiempo que están (que es poco) nos gritan, nos mandan hacer prácticamente todo su trabajo, solo llegan para recetar y se van"

- “las camas que nos daban para el descanso están en las peores condiciones con las sabanas manchadas al igual que las colchas y huelen a guardadas “

- "he gastado bastante dinero comprando batas, guantes, y demás materiales de protección; en el Hospital no nos dan nada. Dicen que los internos deben traer sus propios materiales, es indignante”

- "varias veces no he desayunado para poder llegar al horario de entrada que es a las 5 de la mañana y a veces salimos a las 8 de la noche, es muy estresante” 